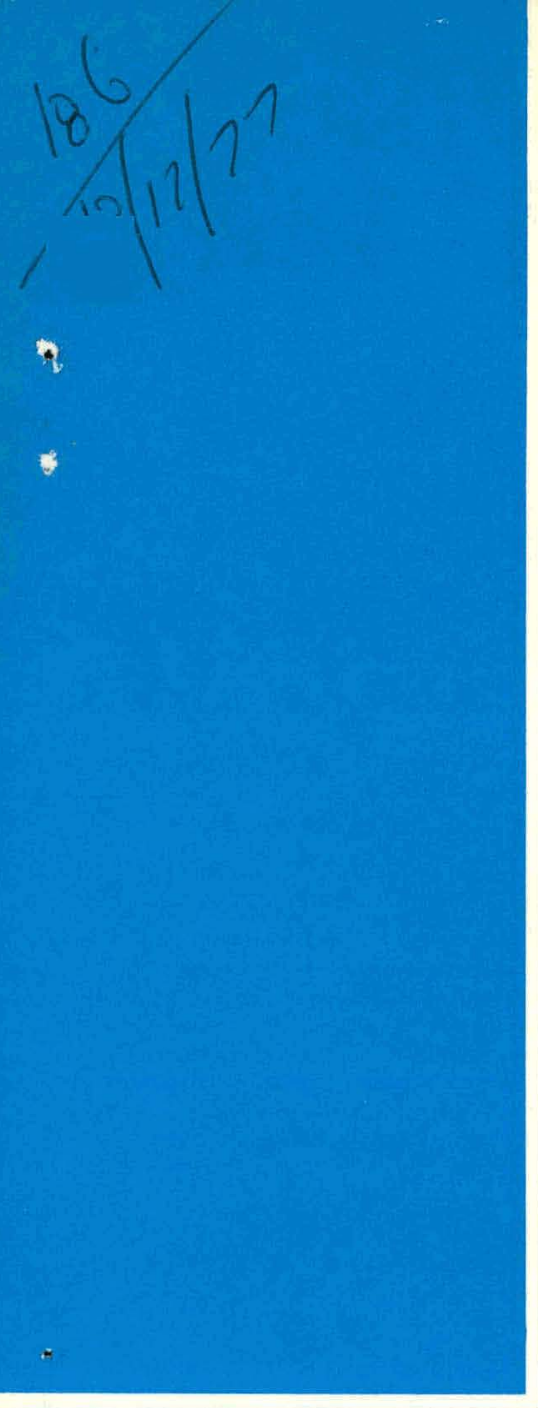

He. $/ 4 Q /$ ORNL/TM-5826

\title{
Separation of Radioactive Krypton from Carbon Dioxide and Oxygen with Molecular Sieves
}

Charles W. Forsberg 


\section{DISCLAIMER}

This report was prepared as an account of work sponsored by an agency of the United States Government. Neither the United States Government nor any agency Thereof, nor any of their employees, makes any warranty, express or implied, or assumes any legal liability or responsibility for the accuracy, completeness, or usefulness of any information, apparatus, product, or process disclosed, or represents that its use would not infringe privately owned rights. Reference herein to any specific commercial product, process, or service by trade name, trademark, manufacturer, or otherwise does not necessarily constitute or imply its endorsement, recommendation, or favoring by the United States Government or any agency thereof. The views and opinions of authors expressed herein do not necessarily state or reflect those of the United States Government or any agency thereof. 


\section{DISCLAIMER}

Portions of this document may be illegible in electronic image products. Images are produced from the best available original document. 


\section{Printed in the United States of America. Available from National Technical Information Service \\ U.S. Department of Commerce 5285 Port Royal Road, Springfield, Virginia 22161 \\ Price: Printed Copy $\$ 5.00$; Microfiche $\$ 3.00$}

This report was prepared as an account of work sponsored by the United States Government. Neither the United States nor the Energy Research and Development Administration/United States Nuclear Regulatory Commission, nor any of their employees, nor any of their contractors, subcontractors, or their employees, makes any warranty, express or implied, or assumes any legal liability or responsibility for the accuracy, completeness or usefulness of any information, apparatus, product or process disclosed, or represents that its use would not infringe privately owned rights. 
ORNL/TM-5826

Dist. Category UC -77

Contract No. W-7405-eng-26

CHEMICAL TECHNOLOGY DIVISION

THORIUM UTILIZATION PROGRAM

Reprocessing Development - Task 200

SEPARATION OF RADIOACTIVE KRYPTON FROM CARBON DIOXIDE AND OXYGEN

WITH MOLECULAR SIEVES

Charles W. Forsberg

Date Published - October 1977

This report was prepared as an account of work

This report was prepared as an account of work

the United States nor the United States Energy

Research and Development Administration, nor any of

their employees, nor any of their contractors,

tubeontractors, of their empinyers, makes any

warranty, express or impled, or assumes any legal

process disclosed, any information, apparatus, product or

pr usefulness of any in tornesents that its use product or

infringe privately owred rights.

OAK RIDGE NATIONAL LABORATORY

Oak Ridge, Tennessee 37830

operated by

UNION CARBIDE CORPORATION

for the

ENERGY RESEARCH AND DEVELOPMENT ADMINISTRATION 


\section{THIS PAGE}

\section{WAS INTENTIONALLY LEFT BLANK}


TABLE OF CONTENTS

Page

Abstract. ..................... 1

1. Introduction, Summary, and Conclusions........... 1

2. Process Selection and Design........... 3

2.1 Introduction .............. 3

2.2 Process Selection. . . . . . . . . . 4 4

2.3 Process Flowsheets .............. . 6

2.3.1 System Location . . . . . . . . . . . . . 6

2.3.2 Process Flowsheet No. 1 . . . . . . . 8

2.3.3 Process Flowsheet No. 2......... . 11

3. Theory..................... 15

3.1 Absorption Data. . . . . . . . . . 15

3.2 Fundamental Data . . . . . . . . . . . 15

3.3 System Analysis. . . . . . . . . . . 17

4. Experiments ................ . . 23

4.1 Experimental Goals . . . . . . . . . 23

4.2 Conceptual Experimental Design . . . . . . . . 23

4.3 Experimental Design. . . . . . . . . . . 24

4.3.1 Molecular Sieve Column. . . . . . . . 24

4.3.2 Molecular Sieves. . . . . . . . . . . 24

4.3.3 Experimental Flowsheet. . . . . . . . 28

4.3.4 Instrumentation . . . . . . . . . . 30

4.4 Experimental Work. . . . . . . . . . 32

4.4.1 Experiments with Linde 4 A Molecular Sieve . . . 32

4.4.2 Series A Experiments with Linde $5 \mathrm{~A}$

Molecular Sieve........... 38 
TABLE OF CONTENTS (cont'd)

Page

4.4.3 Series B Experiments with Linde $5 \mathrm{~A}$

Molecular Sieve. .......... 43

5. Design Considerations and Recommendations. . . . . . 52

5.1 Design Recommendations. . . . . . . . . 52

5.2 System Design and Sizing. . . . . . . . . 54

5.3 Alternative Uses for the $\mathrm{CO}_{2}$-Krypton Separation

System................ 54

6. References ................ 57

Appendix A: Computer Program to Determine Maximum Krypton

Product Concentration .......... 63 
SEPARATION OF RADIOACTIVE KRYPTON FROM CARBON DIOXIDE AND OXYGEN

WITH MOLECULAR SIEVES

Charles W. Forsberg

ABSTRACT

In the reprocessing of HTGR nuclear fuels, the off-gas cleanup system generates a stream containing about $1 \%$ krypton, $90+\% \mathrm{CO}_{2}$, and various amounts of $\mathrm{O}_{2}, \mathrm{~N}_{2}$, and xenon. The krypton is radioactive and must be separated from the $\mathrm{CO}_{2}$ before it is bottled or zeoliteencapsulated for final disposal. A series of theoretical and experimental investigations to find the best method for separating $\mathrm{CO}_{2}$ and krypton under the required conditions showed that $5 \mathrm{~A}$ molecular sieves near $0^{\circ} \mathrm{C}$ and $1.01 \times 10^{5} \mathrm{~Pa}(1 \mathrm{~atm})$ provided the most effective separation. Molecular sieves are powerful solid adsorbents for $\mathrm{CO}_{2}$ but weak adsorbents for krypton. For a typical expected $\mathrm{CO}_{2}-\mathrm{O}_{2}$-krypton gas mixture, a molecular sieve bed adsorbs the $\mathrm{CO}_{2}$, allows the $\mathrm{O}_{2}$ to pass freely through the bed, and concentrates the krypton before it exits the bed. The process selected and investigated is called frontal analysis gas chromatography.

\section{INTRODUCTION, SUMMARY, AND CONCLUSIONS}

In the reprocessing of graphite-based nuclear fuels such as those of the HTGR, the uranium and fission products are separated from the graphite by burning the graphite in pure oxygen. The off-gas (primarily $\mathrm{CO}_{2}$ ) contains most of the radioactive ${ }^{85} \mathrm{Kr}$. Health regulations limit the amount of ${ }^{85} \mathrm{Kr}$ which can be released to the atmosphere. The primary separation of the krypton from the $\mathrm{CO}_{2}$ is effected with the KALC ${ }^{1,2}$ (Krypton Adsorption in Liquid Carbon Dioxide) process, which removes $>99 \%$ of the krypton from the off-gas and concentrates it by a factor of 1000 . The resulting krypton-rich gas product contains about $1 \%$ krypton, $90+\% \mathrm{CO}_{2}$, and various amounts of $\mathrm{O}_{2}, \mathrm{~N}_{2}$, and xenon. Fur 
long-term storage and disposal of the krypton, the $\mathrm{CO}_{2}$ must be removed. This report discusses the theoretical and experimental work in finding and developing a system for this particular separation.

Selective $\mathrm{CO}_{2}$ freeze-out, reaction of $\mathrm{CO}_{2}$ with $\mathrm{Ca}(\mathrm{OH})_{2}$, and adsorption of $\mathrm{CO}_{2}$ onto molecular sieves were investigated for the $\mathrm{CO}_{2}$-krypton separation. Considerations of performance, reliability, remote maintainability, safety, and cost indicated that adsorption on molecular sieves was the optimum separation technique. Therefore, an experimental evaluation of molecular sieves was undertaken.

Molecular sieves are selective adsorbents which strongly adsorb $\mathrm{CO}_{2}$, only weakly adsorb krypton, and do not significantly adsorb $\mathrm{O}_{2}$. It was calculated theoretically and shown experimentally that if a bed of Linde $5 \mathrm{~A}$ molecular sieve was fed a gas containing $\mathrm{O}_{2}$, krypton, and $\mathrm{CO}_{2}$, the $\mathrm{CO}_{2}$ was totally adsorbed, the $\mathrm{O}_{2}$ flowed through the bed, and the krypton was concentrated as in a frontal analysis chromatograph. The gas exiting the bed consisted of initially pure $0_{2}$, followed successively by concentrated krypton and the feed gas. The molecular sieve bed can easily be regenerated by heating to $200^{\circ} \mathrm{C}$, which drives off the $\mathrm{CO}_{2}$.

The following conclusions were drawn from a series of experiments designed to study the operation of a bed of Linde $5 \mathrm{~A}$ molecular sieve maintained at $0^{\circ} \mathrm{C}$ and fed a gas composed of $93.09 \% \mathrm{CO}_{2}, 5.43 \% 0.2$, and 1.48\% krypturn:

1. The krypton and oxygen products exiting molecular sieve beds contained < $10 \mathrm{ppm}$ of $\mathrm{CO}_{2}$; in other words, essentially complete separation of $\mathrm{CO}_{2}$ and krypton is obtained by using molecular sieves. 
2. The rate of adsorption of $\mathrm{CO}_{2}$ onto molecular sieves is very fast; that is, mass transfer does not limit the design and/or performance of a molecular sieve bed.

3. The adsorption of $\mathrm{CO}_{2}$ releases tremendous amounts of heat. Removal of the heat of adsorption in a molecular sieve bed is the major problem in system design.

4. Desorption of adsorbed $\mathrm{CO}_{2}$ from a molecular sieve bed is easily accomplished by heating the bed to $200^{\circ} \mathrm{C}$.

5. With the above feed gas, the resulting krypton gas product was consistently $>50 \%$ in krypton with the residual being $0_{2}$. The molecular sieve partially separated $\mathrm{O}_{2}$ and krypton in addition to a total krypton- $\mathrm{CO}_{2}$ separation.

It is concluded that use of a molecular sieve system is the preferred method for the final separation of $\mathrm{CO}_{2}$ and krypton under the conditions expected to exist in an HTGR nuclear fuel reprocessing plant.

\section{PROCESS SELECTION AND DESIGN}

\subsection{Introductiun}

Because of the potential health hazards ${ }^{3}$ of a worldwide increase in ${ }^{85} \mathrm{Kr}$, a radioactive gas produced during fission, most of the krypton containing ${ }^{85} \mathrm{Kr}$ must be removed from the off-gas stream of HTGR nuclear fuel reprocessing plants before its release to the atmosphere. The plant off-gas contains $\sim 95 \% \mathrm{CO}_{2}, 10$ to $15 \mathrm{ppm}$ of krypton, and varying amounts of $\mathrm{O}_{2}, \mathrm{~N}_{2}$, and xenon. ${ }^{4}$ It is proposed to use the $\mathrm{KALC}^{1,2}$ process to 
remove $>99 \%$ of this krypton from the off-gas and concentrate it by a factor of 1000. KALC should produce a krypton-rich stream of about $1 \%$ krypton, 0 to $3 \%$ xenon, traces of $\mathrm{O}_{2}$, and $95+\% \mathrm{CO}_{2}$. For temporary storage and perhaps disposal, the krypton will be bottled in gas cylinders or encapsulated in zeolites. ${ }^{5}$ Because of economic and safety ${ }^{6}$ considerations, the bottled krypton should have a krypton content of $>10 \%$ and contain little or no $\mathrm{CO}_{2}$. Removal of $\mathrm{CO}_{2}$ is desired to avoid the possibility of various chemical reactions activated by the krypton radiation field between the $\mathrm{CO}_{2}, \mathrm{O}_{2}$, and bottle materials. Section 2.2 evaluates alternative processes for this final separation. Sections 2.3 and 2.4 describe the chosen separation processes in detail.

\subsection{Process Selection}

The following criteria ${ }^{7}$ were applied in selecting the system to be used for the final separation of krypton:

1. The process must concentrate the krypton in the $\mathrm{CO}_{2}$ gas stream by at least a factor of 10 . The nominal krypton feed concentration is expected to be $\sim 1 \%$.

2. All the $\mathrm{CO}_{2}$ should be removed. Conversion of $\mathrm{CO}_{2}$ to $\mathrm{CO}, \mathrm{O}_{2}$, and other compounds can occur in the presence of a ${ }^{85} \mathrm{Kr}$ radiation field in storage cylinders. 6,8 Some of these compounds could accelerate corrosion of the gas cylinders.

3. The materials of construction and any process materials used should be noncombustible. Oxygen will be present, and radiation fields could provide the mechanisms to start combustion. 
4. The process must be able to accept highly variable feed gas compositions. Any process upset in other plant off-gas equipment might propagate to this system.

5. The process should be highly reliable and easily maintainable in a radioactive environment.

6. The process should be easily and accurately scalable from bench scale to full size. If we make the assumptions that KALC concentrates the krypton by a factor of 1000 from $10 \mathrm{ppm}$ to $1 \%$ krypton, a full-scale plant handles the fuel from power reactors producing $50 \mathrm{GW}(\mathrm{e})$, and the plant operates 300 days per year, then the gas flow rate to this system is $1.83 \mathrm{scfm}$ for a full-scale plant.

7. The process should produce no by-product wastes. Any material of this nature will probably be contaminated with ${ }^{85} \mathrm{Kr}$ and will have to be treated as radioactive waste.

The following types of $\mathrm{CO}_{2}$ removal systems ${ }^{9}, 10$ were evaluated:

1. Carbon dioxide can be removed by reaction with a chemical reagent such as $\mathrm{Ca}(\mathrm{OH}) ?^{11,12}$ to yield a solid reaction product such as $\mathrm{CaCO}_{3}$. This approach was considered unacceptable because it either produces an additional solid waste stream with disposal problems or involves a complex system for regenerating the reagents and the $\mathrm{CO}_{2}$.

2. Carbon dioxide can be removed by adsorption in a wide variety of solvents. The system involved would be similar to KALC except that a different solvent would be used and $\mathrm{CO}_{2}$, not krypton, would 
be concentrated. This approach was rejected because of the complexity of the equipment.

3. Carbon dioxide can be removed by selectively freezing the $\mathrm{CO}_{2}$ out of the gas mixture. If the system is operated at low pressures, the $\mathrm{CO}_{2}$ is converted from a gas to a solid, which alters the heat transfer coefficient of the cooler. Such devices with variable heat and mass transfer coefficients as a function of time are very difficult and risky to scale up. If the system is operated at high pressures, the $\mathrm{CO}_{2}$ gas liquefies and the liquid $\mathrm{CO}_{2}$ dissolves some of the krypton gas, making clean separations of $\mathrm{CO}_{2}$ and krypton difficult. In either case, this approach was considered unacceptable due to the uncertainties in scaling such equipment up to industrial size.

4. Carbon dioxide can be adsorbed selectively by a variety of adsorbents, including molecular sieves, charcoal, and silica yel. The adsorbents can bè regenerated simply by heating. This method was selected as the preferred approach for $\mathrm{CO}_{2}$ removal. Molecular sieves ${ }^{13,14}$ were chosen as the adsorbent because they are extremely inert, noncombustible, and resistant to damage from high radiation fields.

\subsection{Process Flowsheets}

\subsubsection{System location}

Figure 2.1 is a simplified front-end flowsheet of the HTGR fuel reprocessing plant, showing the location of the krypton removal equipment. ${ }^{15}$ The $\mathrm{CO}_{2}$ removal equipment is located in such a way that, if 


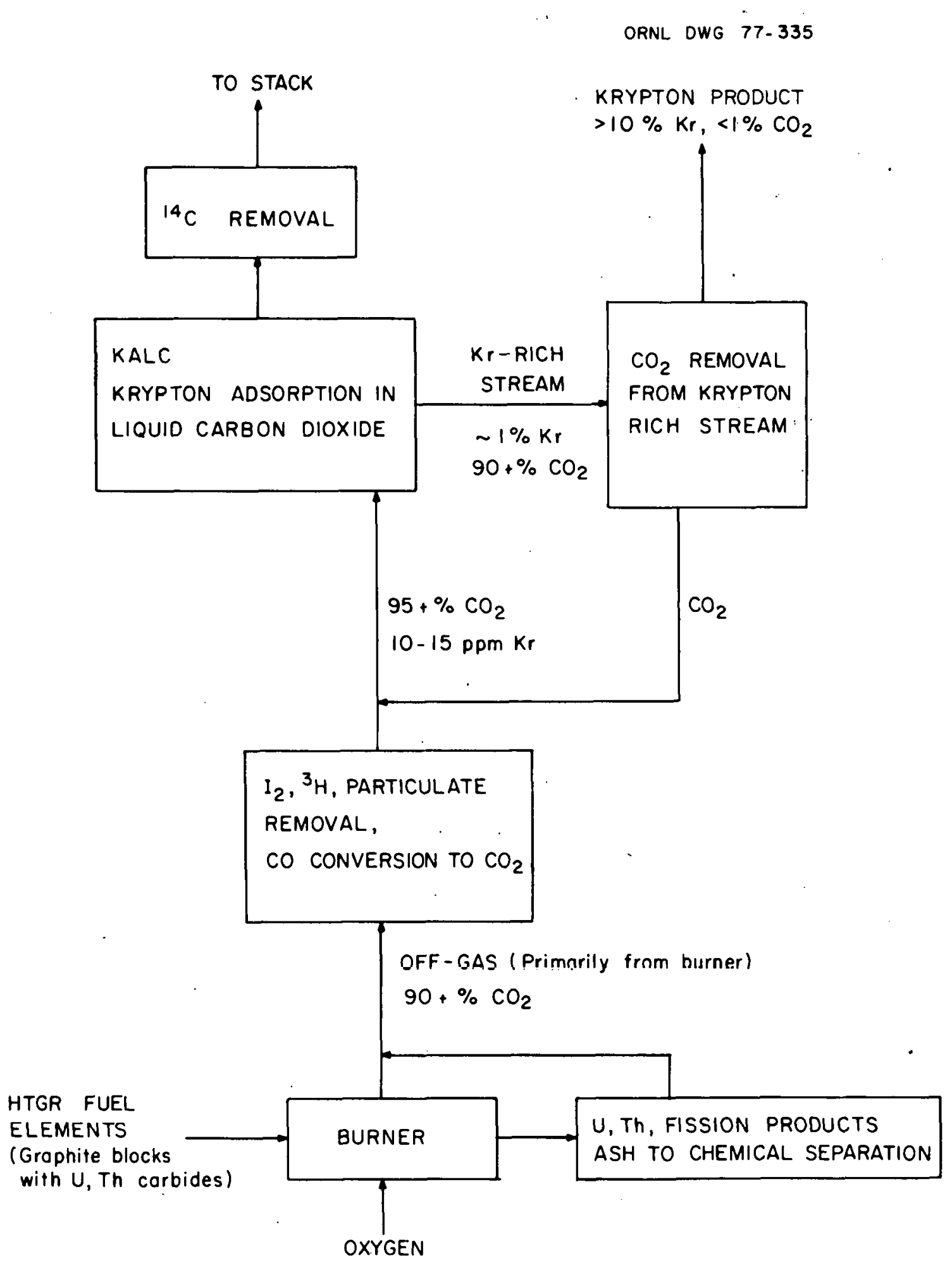

Fig. 2.1. Flowsheet of off-gas system of HTGR fuel reprocessing plant. 
the $\mathrm{CO}_{2}$ removed from the krypton-rich gas stream ( $1 \%$ krypton) is contaminated with krypton, it can be recycled to the front end of the main krypton removal equipment. The flow rate of the $\mathrm{CO}_{2}$ removal system is only about one-thousandth that of the main off-gas stream; hence total recycle of this $\mathrm{CO}_{2}$ will not significantly change the size of the major equipment items.

\subsubsection{Process flowsheet No. 1}

The simplest filowsheet for the continuous separation of krypton and $\mathrm{CO}_{2}$ is shown in Fig. 2.2. The process consists of two columns filled with molecular sieves, ${ }^{14}$ which are aluminosilicate crystals that can adsorb $\mathrm{CO}_{2}$ up to $20 \%$ of their own weight. This material is chemically inert and can be heated to several hundred degrees Centigrade without damage.

Some types of molecular sieves, such as Linde $4 \mathrm{~A}$, adsorb $\mathrm{CO}_{2}$ but not krypton. 16,17 other molecular sieves, such as Linde $5 A$, adsorb both $\mathrm{CO}_{2}{ }^{1 \%, 18}$ and krypt.nn; ${ }^{19-26}$ hnwever, the $\mathrm{Cn}_{2}$ is more strongly adsorbed and displaces the krypton held by the molecular sieve. Molecular sieves such as type 5A may be used in preference to type 4A because of their faster adsorption kinetics and higher adsorption capacities. 27 Molecular sieve $5 \mathrm{~A}$ adsorbs about $17.5 \%$ of its own weight in $\mathrm{CO}_{2}{ }^{18}$ in the presence of a gas mixture containing $95 \% \mathrm{CO}_{2}$ at $1 \mathrm{~atm}$ and $0^{\circ} \mathrm{C}$. At 1 atm and $200^{\circ} \mathrm{C}$, it adsorbs only $1 \%$ of its weight in $\mathrm{CO}_{2}$. Such characteristics allow molecular sieves to be used for selectively adsorbing $\mathrm{CO}_{2}$ out of a gas stream at low temperatures and to be regenerated at high temperatures. The adsorption of $\mathrm{CO}_{2}$ releases large amounts of heat; hence 
ORNL DWG 77.336

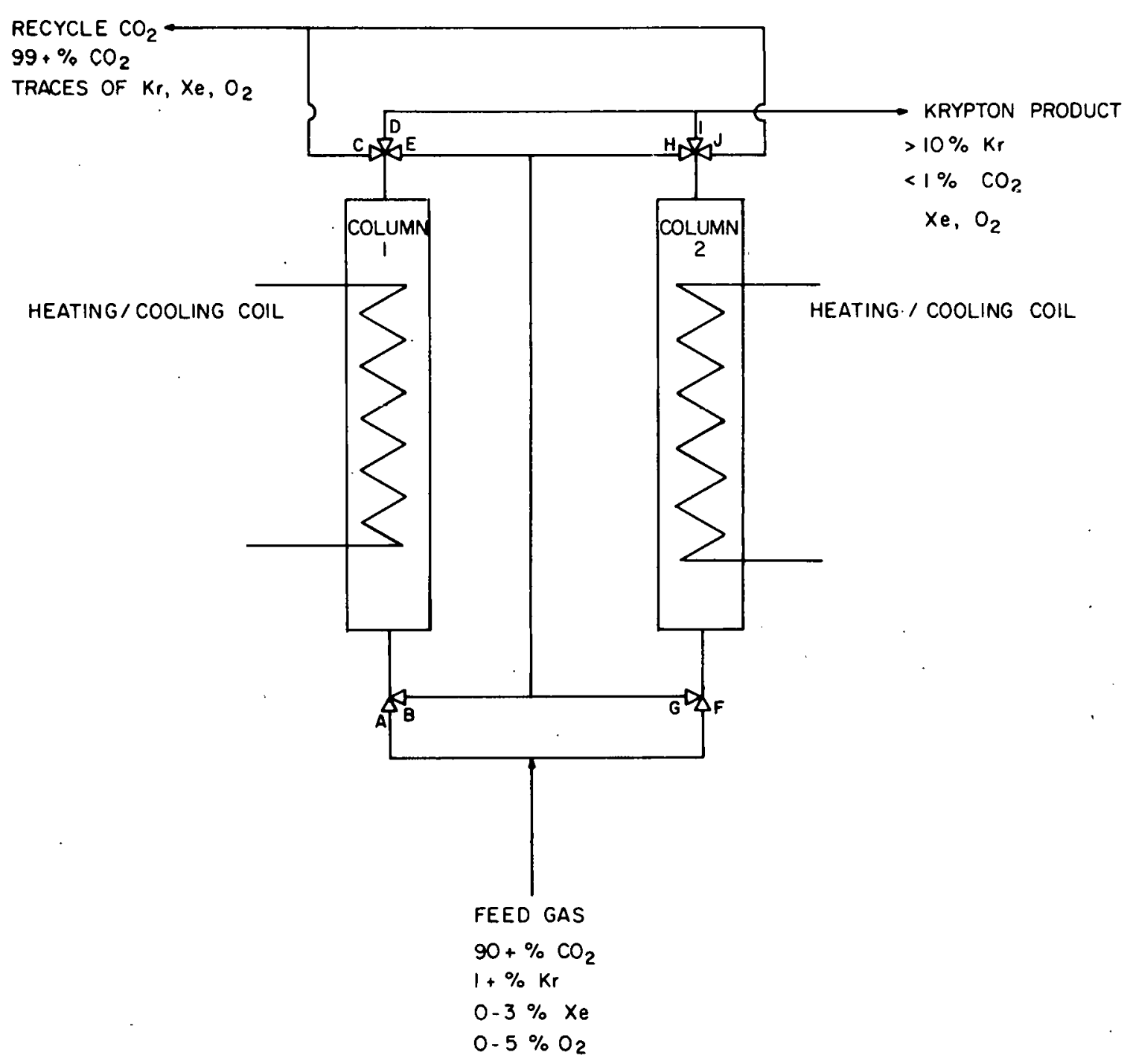

Fig. 2.2. Simple flowsheet for separation of $\mathrm{CO}_{2}$ and krypton. 
it is necessary to cool the bed continuously when adsorbing $\mathrm{CO}_{2}$ and to heat the bed continuously when deadsorbing $\mathrm{CO}_{2}$.

The actual separation process, as shown in Fig. 2.2, works as follows: The feed gas is admitted through valve $A$ into column 1, a clean molecular sieve bed maintained at 1 atm of pressure and $0^{\circ} \mathrm{C}$. The $\mathrm{CO}_{2}$ is adsorbed on the bed, and the krypton and other gases exit the bed through valve $D$ to the krypton product line. As the $\mathrm{CO}_{2}$ adsorption front approaches the top of column 1, the exit gas from this column is diverted through values $E$ and $G$ into column 2, which also contains clean molecular sieve. The krypton product exits from column 2 via valve I. After column 1 becomes saturated with $\mathrm{CO}_{2}$, the feed gas is diverted directly to column 2 through valve $F$ while vaives $E$ and $G$ are closed. At this time, valve $C$ is opened and column 1 is heated to at least $200^{\circ} \mathrm{C}$. The adsorbed $\mathrm{CO}_{2}$ is drawn off the column, valve $\mathrm{C}$ is then closed, valve $D$ is opened, and the column is cooled to $0^{\circ} \mathrm{C}$. When the $\mathrm{CO}_{2}$ adsorption front in column 2 approaches the top of column 2, valve $I$ is closed and valves $B$ and $H$ are opened. This diverts the flow from the top of column 2 to the bottom of column 1 . When column 2 is saturated with $\mathrm{CO}_{2}$, the feed gas is sent directly to column $I$ via valve $A$, and valves $B, H$, and $F$ are closed. At this time, valve $J$ is opened and column 2 is heated to at least $200^{\circ} \mathrm{C}$ to regenerate the molecular sieve. After regeneration, valve $J$ is closed, valve $I$ is opened, and the column is cooled to $0^{\circ} \mathrm{C}$. At this point, the two columns have gone through one complete cycle, separating $\mathrm{CO}_{2}$ from krypton.

The instrumentation and controls for such a system are simple. Because of the large amounts of heat released during the adsorption of 
$\mathrm{CO}_{2}$, the adsorption front in each column can be followed by thermocouples. Alternatively, the undiluted krypton with $\mathrm{CO}_{2}$ removed is much more radioactive than the feed gas; hence radiation detectors can easily determine the location of the $\mathrm{CO}_{2}$ adsorption front which divides the krypton product gas from the feed gas. Either thermocouple or radiation detector readings can be used to trigger the opening and closing of the individual valves.

Various types of molecular sieves could be used; experimentally, both Linde $4 \mathrm{~A}$ and $5 \mathrm{~A}$ molecular sieves are satisfactory. The system pressure should be $\sim 10^{5} \mathrm{~Pa}(\sim 1 \mathrm{~atm})$. The adsorption of $\mathrm{CO}_{2}$ increases with pressure up to slightly above $10^{5} \mathrm{~Pa}(1 \mathrm{~atm})$. Colder temperatures also increase $\mathrm{CO}_{2}$ adsorption in molecular sieves, but the increase tends to level off around $0^{\circ} \mathrm{C}$; thus little advantage is gained by operating below $0^{\circ} \mathrm{C}$.

\subsubsection{Process flowsheet No. 2}

An alternative molecular. sieve process flowsheet (Fig. 2.3) permits separation of a gas stream of $\mathrm{O}_{2}$, krypton, and $\mathrm{CO}_{2}$ into a pure $\mathrm{O}_{2}$ stream, an $\mathrm{O}_{2}$-krypton stream, and a pure $\mathrm{CO}_{2}$ stream. At the cost of greater complexity, this flowsheet produces a more highly concentrated stream of krypton. It is based on the particular characteristics of molecular sieve $5 \mathrm{~A}$, which strongly adsorbs $\mathrm{CO}_{2}, 17,18$ weakly adsorbs krypton, $19-26$ and does not significantly adsorb $0_{2} \cdot{ }^{28}$

Let us assume that a single column of $5 \mathrm{~A}$ molecular sieve is fed a mixture of $\mathrm{O}_{2}$, krypton, and $\mathrm{CO}_{2}$. As the feed gas enters the column, the krypton and $\mathrm{CO}_{2}$ are adsorbed; the $\mathrm{O}_{2}$, on the other hand, is unadsorbed and flows directly through the column. As more feed gas enters, 


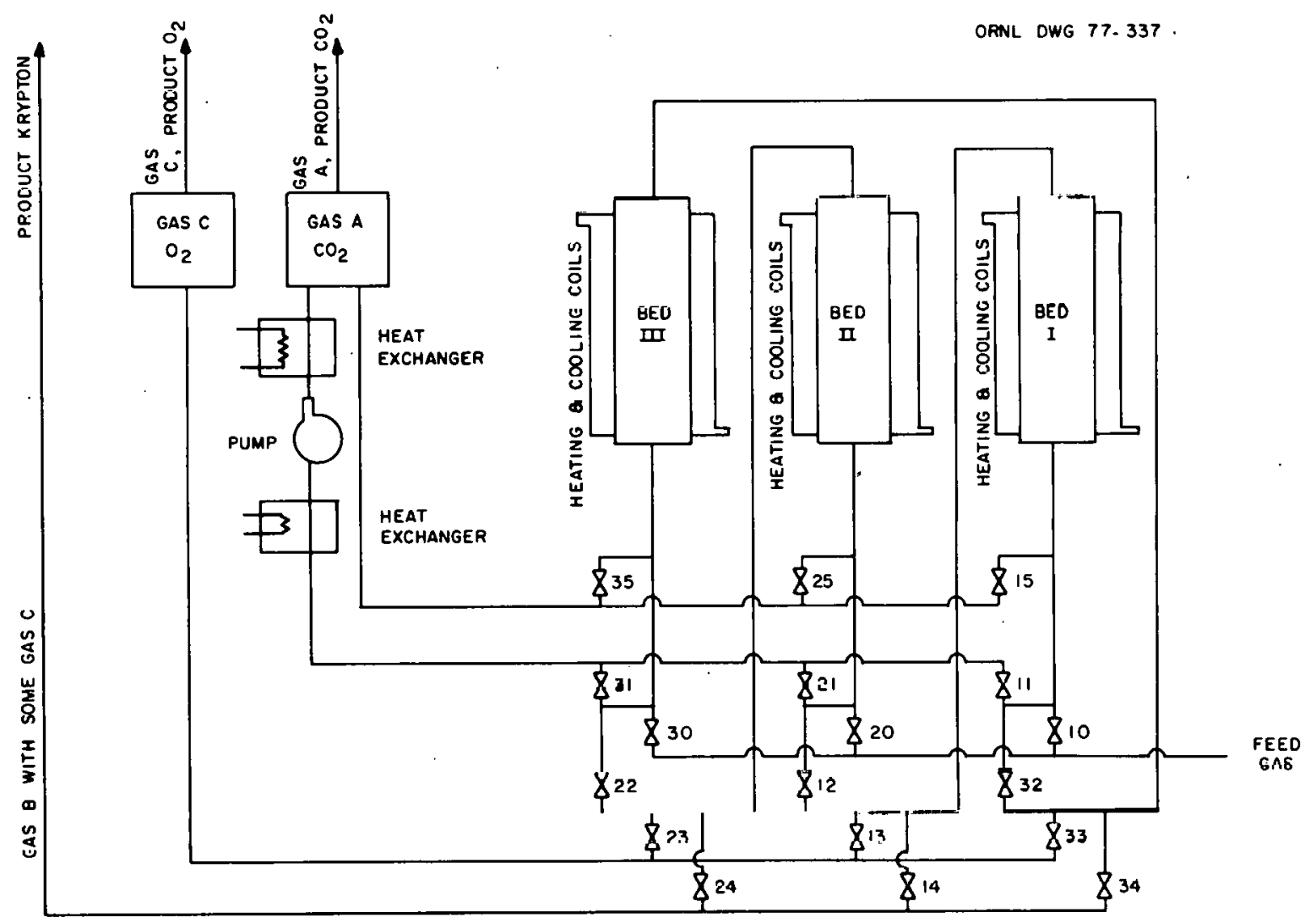

Fig. 2.3. Process flowsheet No. 2. 
the $\mathrm{CO}_{2}$, which is more strongly adsorbed, displaces the krypton from the molecular sieve bed. After a few minutes of operation of a single bed, three zones are noted: a zone of clean bed near the gas exit with oxygen in the gas phase, a zone of krypton adsorbed on the bed with $\mathrm{O}_{2}$ and krypton in the gas phase, and a zone with $\mathrm{CO}_{2}$ on the bed and feed gas in the gas phase. Analysis of the gas leaving the bed with time shows pure $\mathrm{O}_{2}$ initially, followed successively by a krypton- $\mathrm{O}_{2}$ gas mixture and the feed gas when the molecular sieve is saturated with $\mathrm{CO}_{2}$. This process is described as frontal analysis chromatography in the literature. ${ }^{29,30}$ It has been investigated but apparently has not been used on any significant scale.

Let us consider one complete cycle for bed I. Feed gas is fed into a clean column, first via valve 32 from bed III and then via valve 10 from the main feed gas line. Valve 13 is opened to allow the oxygen from the feed gas to flow directly through the column to the $\mathrm{O}_{2}$ product line while the krypton and $\mathrm{CO}_{2}$ are adsorbed. The bed is constantly cooled to remove the heat of adsorption of $\mathrm{CO}_{2}$ and krypton. As the process continues, krypton adsorbs onto the top portion of the bed and $\mathrm{CO}_{2}$ adsorbs on the bottom portion. When the krypton approaches the top of the column, valves 12 and 23 are opened while valve 13 is closed. The transition zone of gas leaving column 1, where the gas goes from pure $\mathrm{O}_{2}$ to a constant $0_{2}$-krypton mixture, is sent to column 2. After it has been determined that a constantcomposition mixture of $0_{2}$-krypton is leaving column 1 , valve 12 is closed and valve 14 is opened; this diverts the gas mixture to the krypton product line. As the second gas transition regiun between the 
krypton $-\mathrm{O}_{2}$ mixture and the feed gas approaches the top of column 1, valve 14 is closed and valve 12 is opened, diverting the gas to column 2. After the gas transition zone has passed into column 2, valve 10 is closed while valve 20 is opened. This diverts the feed gas to column 2. Valve 15 , which supplies pure $\mathrm{CO}_{2}$ to column 1 , is then opened to allow just enough $\mathrm{CO}_{2}$ sweep gas through column 1 to push the feed gas present in the pipes and between the molecular sieve particles out of the bed. At. this time, valve 12 is closed, valve 11 is opened, and the bed is heated to at least $200^{\circ} \mathrm{C}$, driving the pure $\mathrm{CO}_{2}$ off the molecular sieve to the $\mathrm{CO}_{2}$ product line. A small compressor lowers the gas pressure, resulting in very little residual $\mathrm{CO}_{2}$ on the molecular sieve. Valve 11 is closed, valve 13 is opened, and the bed is subsequently cooled back to $0^{\circ} \mathrm{C}$ from the bottom of the column to the top. This procedure ensures that the small amount of $\mathrm{CO}_{2}$ remaining in column 1 will be readsorbed on the molecular sieve near the bottom of the column so that, when feed gas enters, there is no risk of $\mathrm{Cn}_{2}$ existing with the initial $\mathrm{O}_{2}$ product. With this rilld cooling, bed 1 is. ready to begin its cycle again. The other columns go through an identical cycle, yielding pure $\mathrm{O}_{2}, \mathrm{CO}_{2}$, and an $\mathrm{O}_{2}$-krypton product mixture.

This process can be used both to purify krypton and, possibly, to remove krypton from the off-gas directly without the use of the KALC system. This second alternative will be discussed in Sect. 5 . If xenon is added to the feed gas, the result is a gas mixture of $\mathrm{O}_{2}$ krypton and xenon exiting each bed after the $0_{2}$-krypton mixture but before the feed gas leaves it. 


\section{THEORY}

\subsection{Absorption Data}

Large amounts of data have been collected, and extensive theoretical analysis ${ }^{14,31-33}$ has been made of the adsorption of various gases on molecular sieves. This section reviews the data and describes the method of analysis used to predict experimental behavior.

\subsection{Fundamental Data}

A search of the literature reveals extensive data concerning the adsorption characteristics of $\mathrm{O}_{2},{ }^{28} \mathrm{CO}_{2},{ }^{16-18}$ and krypton ${ }^{19-26}$ on molecular sieves. Figure 3.1 shows the adsorption curves used for $\mathrm{CO}_{2}$ and krypton on Linde $5 \mathrm{~A}$ molecular sieve at $0^{\circ} \mathrm{C}$ and $200^{\circ} \mathrm{C}$ in most calculations. The $\mathrm{CO}_{2}$ adsorption curve was provided by the Linde Division of Union Carbide Corporation. 18 The krypton adsorption curve is the one reported by Kitani. 19

Extreme care must be taken in using literature values of adsorption in the design of industrial equipment. Linde $5 \mathrm{~A}$ molecular sieve, like other commercial molecular sieves, contains about 80 wt \% active crystals and 20 wt \% inert clay binder to hold the crystals together. 31 Many of the data reported in the literature were obtained on pure molecular sieve crystals. The value of 0.8 in the equation for krypton adsorption in Fig. 3.1 is included to correct for the difference between literature values and commercial products.

Figure 3.1 appears to show adsorption linear with pressure. This is true for a reasonable range of pressures; however, as shown for $\mathrm{CO}_{2}$ 


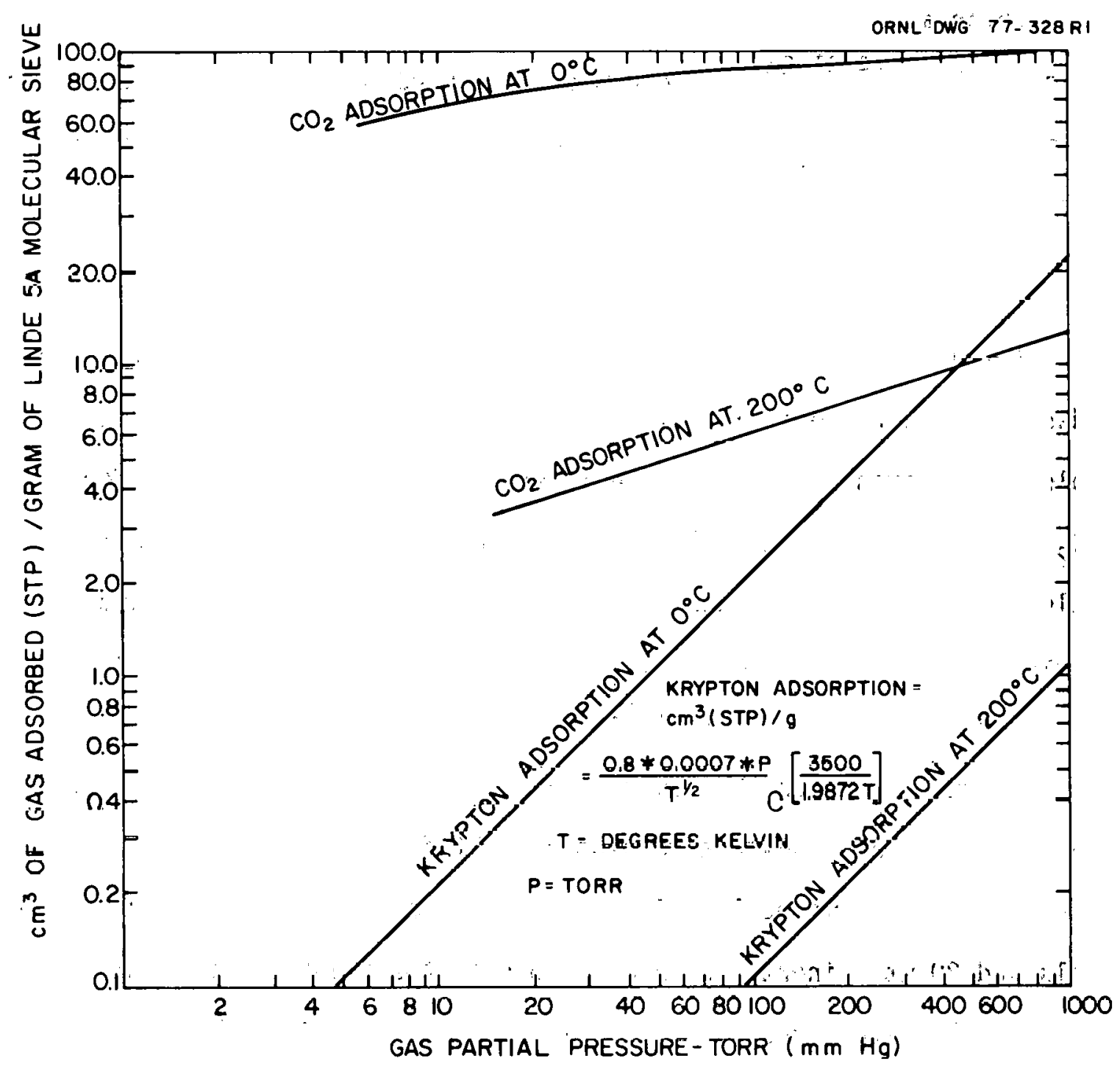

Fig. 3.1. Adsorption of carbon dioxide and krypton on Linde $5 \mathrm{~A}$ molecular sieve. 
at $0^{\circ} \mathrm{C}$, adsorption begins to approach a limit as loading of the molecular sieve proceeds.

\subsection{System Analysis}

If a molecular sieve bed could be sectioned along its major axis and the gas analyzed at each location, the results for an oxygen-krypton$\mathrm{CO}_{2}$ system would be similar to those shown in Fig. 3.2. As explained earlier in Section 2.3.3, three distinct zones are apparent: a feed gas zone, a krypton-rich zone, and an oxygen zone separated by two transition regions. As feed gas is fed to the system, the oxygen zone is pushed out by an expanding krypton zone, which in turn is displaced by the feed gas zone. Note that the expanding krypton zone implies a longer section of molecular sieve bed with adsorbed krypton but does not alter the maximum krypton concentration.

For engineering and design calculations, three factors in Fig. 3.2 could be of interest: the variation of gas composition as a function of distance in transition region 1 , the maximum concentration of the krypton at quasi-steady-state conditions in Zone $B$, and the variation of gas composition as a function of distance in transition region 2. Experiments, which are discussed in Section 4, clearly show that the gas transition regions 1 and 2 are very narrow compared to the bed length due to very fast mass transfer. As a consequence, the details of what occurs in these transition regions can be neglected for a practical bed design. For this reason, a simple, iterative numerical procedure was developed to determine only the maximum krypton concentration in Zone B without 
ORNL DWG $77-1430$

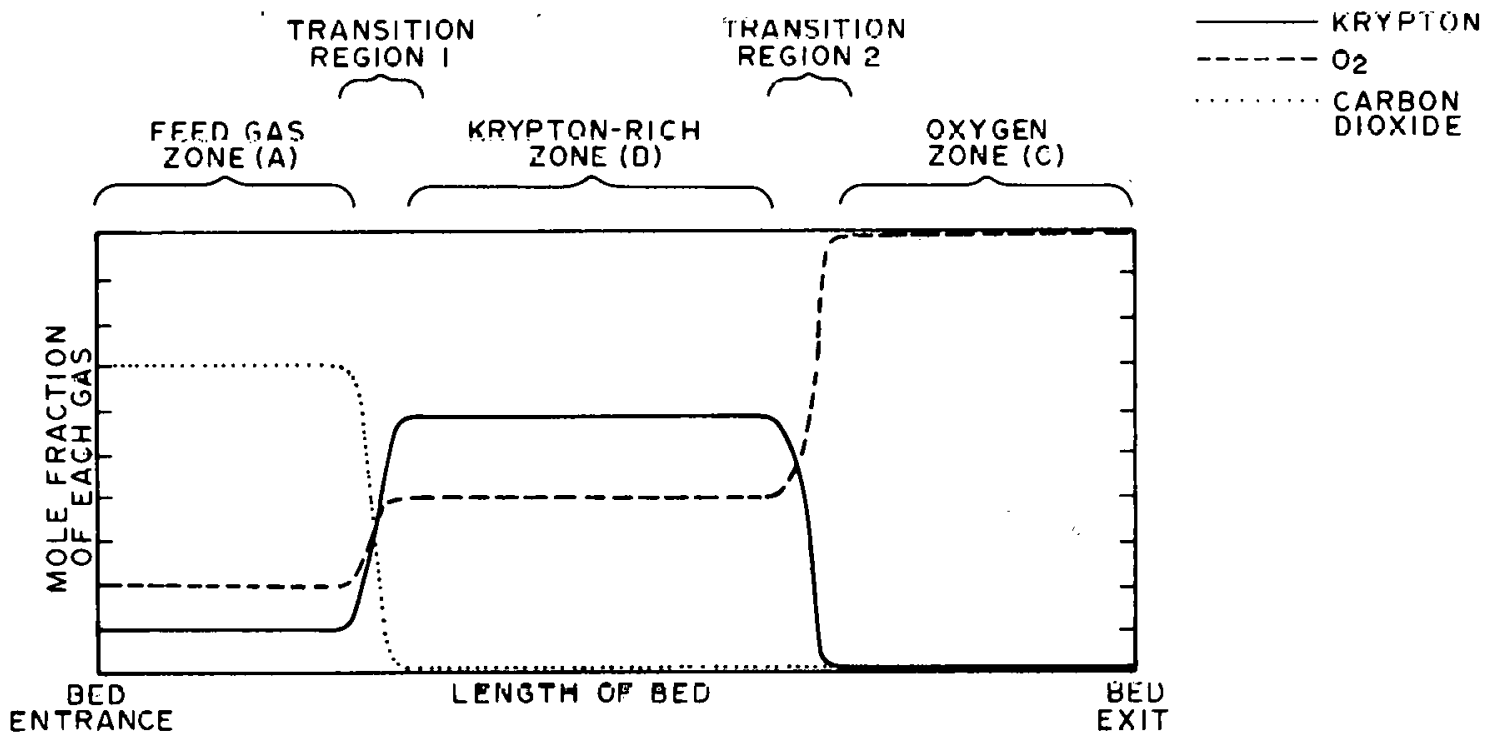

Fig. 3.2. Gas composition vs molecular sieve bed position. 
going into the complexities of transient mass transfer. The calculated results obtained from this simplified numerical procedure, which totalTy ignores kinetics, are in agreement with experiments as discussed in Section 4 .

The computer program, which is listed in Appendix $A$, requires the following as input data: '(1) temperature of the molecular sieve, (2) pressure of the molecular sieve, (3) feed gas composition, and (4) adsorption isotherms as a function of temperature and partial pressure for each gas for each type of molecular sieve considered.

Adsorption isotherm data are available both in the literature and from manufacturers in the form of graphs and equations for $0_{2},{ }^{28}$ $\mathrm{CO}_{2},{ }^{16-18}$ krypton, ${ }^{19-26}$ and other gases.

The iterative numerical procedure (Fig. 3.3) to find the maximum krypton concentration in Zone $B$ is based on following the progress of $1 \mathrm{~cm}^{3}$ of feed gas in the molecular sieve bed. As an example, let us assume that a feed gas composed of $93.09 \% \mathrm{CO}_{2}, 1.48 \%$ krypton, and $5.43 \% 0_{2}$, by volume, is introduced into a bed of $5 \mathrm{~A}$ Linde molecular sieve maintained at a constant temperature of $0^{\circ} \mathrm{C}$ and $1 \mathrm{~atm}$ of pressure. This volume of gas is unaffected and unadsorbed as it passes through the first part of the bed, which has been saturated with $\mathrm{CO}_{2}$. However, it soon reaches a transition zone, where $\mathrm{CO}_{2}$ is adsorbed on the bed while krypton is desorbed. At this point, the $\mathrm{CO}_{2}$ in the feed gas, $0.9309 \mathrm{~cm}^{3}$, is adsorbed onto the bed, thereby displacing the previously adsorbed krypton. 
ORNL OWG $77-338$ RI

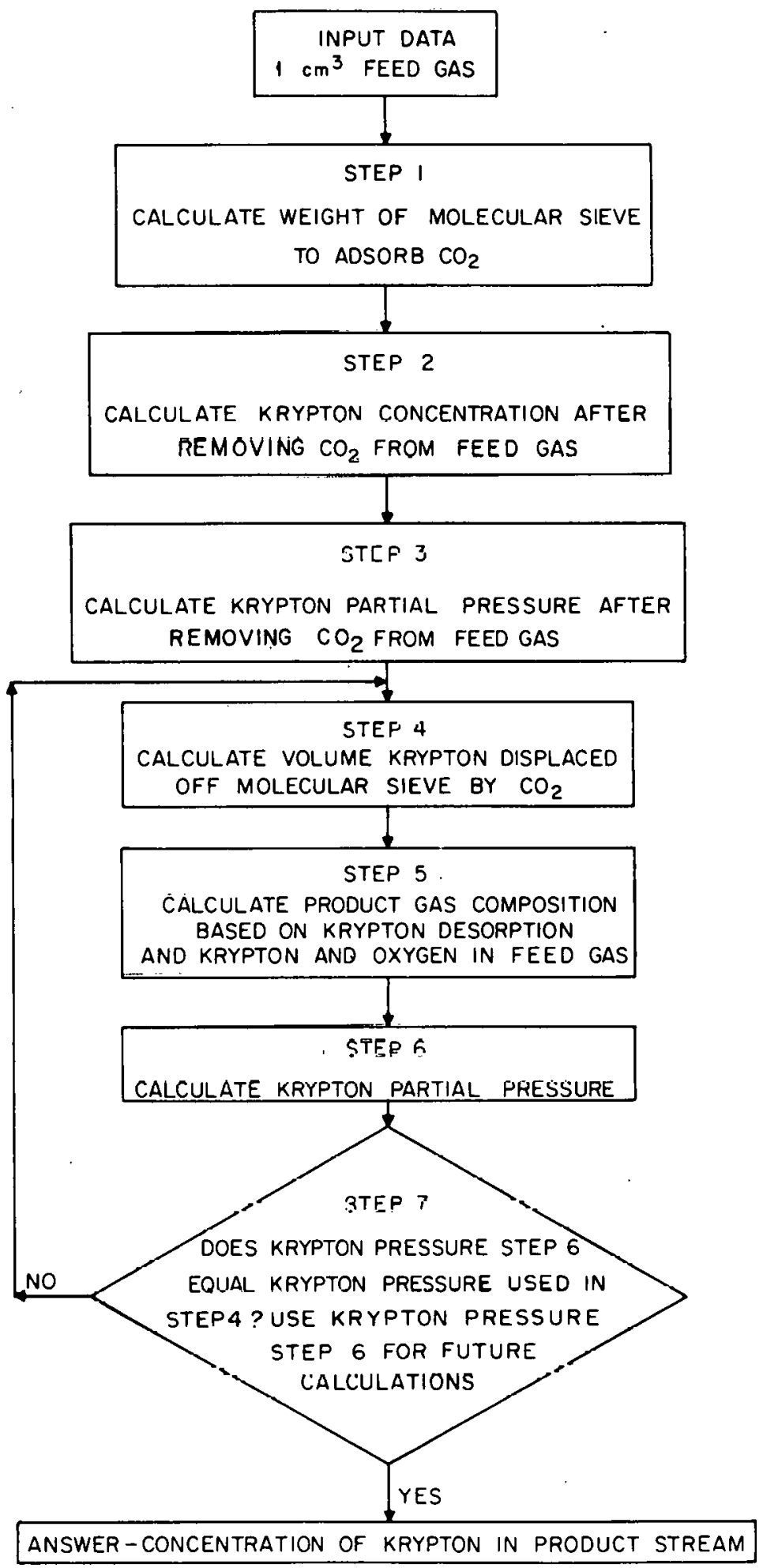

Fig. 3.3. Iterative numerical procedure for calculating krypton product concentration. 
Isotherm adsorption charts for $5 \mathrm{~A}$ molecular sieve show that, at $0^{\circ} \mathrm{C}$ and a $\mathrm{CO}_{2}$ partial pressure of $0.9309 \mathrm{~atm}, 89.15 \mathrm{~cm}^{3}$ of $\mathrm{CO}_{2}$ is adsorbed per gram of molecular sieve; that is, $0.9309 \mathrm{~cm}^{3}$ of $\mathrm{CO}_{2}$ would be totally adsorbed onto $0.010442 \mathrm{~g}$ of molecular sieve (Fig. 3.3, step 1).

Now the initial composition of the remaining gas without $\mathrm{CO}_{2}$ but including the krypton displaced by $\mathrm{CO}_{2}$ adsorption can be calculated (Fig. 3.3, step 2). The feed gas without $\mathrm{CO}_{2}$ consists of $0.0148 \mathrm{~cm}^{3}$ of krypton and $0.0543 \mathrm{~cm}^{3}$ of $\mathrm{O}_{2}$ and hence has a krypton concentration of $(0.0148) /(0.0148+0.0543)$, or $21.4 \%$. At $1 \mathrm{~atm}$ of pressure, the partial pressure of krypton is therefore 162.77 torr (Fig. 3.3, step 3).

The equation given by Kitani and Takada ${ }^{19}$ for determining the volume of krypton that is adsorbed on $5 A$ molecular sieve is:

$$
V=\frac{0.8 * 0.0007 * P}{T^{1 / 2}} \exp \left[\frac{3500}{1.9872 * T}\right] \text {, }
$$

where

$$
\begin{aligned}
& P=\text { pressure, torr }, \\
& T=\text { temperature, }{ }^{\circ} \mathrm{K} .
\end{aligned}
$$

This equation implies that $3.482 \mathrm{~cm}^{3}$ of krypton per gram can be adsorbed on $5 \mathrm{~A}$ molecular sieve at $0^{\circ} \mathrm{C}$ and 162.77 torr of krypton partial pressure. 
Consequently, the $\mathrm{CO}_{2}$ which was adsorbed onto $0.010442 \mathrm{~g}$ of molecular sieve displaced $0.0363573 \mathrm{~cm}^{3}$ of krypton from the molecular sieve that was in equilibrium with the krypton gas above it (Fig. 3.3, step 4). Some oxygen is coadsorbed with the krypton and also pushed off the bed with $\mathrm{CO}_{2}$; however, this amount is so small that it can be ignored.

With the krypton from the feed gas $\left(0.0148 \mathrm{~cm}^{3}\right)$, the krypton desorbed from the molecular sieve $\left(0.0363573 \mathrm{~cm}^{3}\right)$, and the oxygen from the feed gas $\left(0.0543 \mathrm{~cm}^{3}\right)$, the new krypton product is calculated to have a krypton concentration of $48.51 \%$ ( Fig, 3.3, step 5). Based on this concentration and $1 \mathrm{~atm}$ of pressure, the partial krypton vapor pressure is calculated to be 368.68 torr (Fig. 3.3, step 6).

The final calculated krypton product partial pressure (368.68 torr) differs from the estimated krypton vapor pressure (162.77 torr) used to calculate the amount of krypton that was displaced from the molecular sieve by the $\mathrm{CO}_{2}$. If these two values had been identical, the final krypton product concentration would have been known. Clearly, the original estimate of the partiai pressure of krypton over the molecular sieve saturated with krypton was low because it did not account for the increase in krypton partial pressure caused by the krypton displaced with $\mathrm{CO}_{2}$. The calculations from step 4 (Fig. 3.3) onward, which include calculation of the amount of krypton desorbed from $0.010442 \mathrm{~g}$ of molecular sieve, must be repeated using the new higher vapor pressure, 368.68 torr (step 7). This iteration procedure (Fig. 3.3, step 7) is repeated until the partial pressure of krypton used to calculate the amount of krypton displaced by the $\mathrm{CO}_{2}$ gives the final concentration 
of krypton to the desired degree of accuracy. For this example, the final gas composition upon convergence of this numerical technique is $71.49 \%$ krypton and $28.57 \% \mathrm{O}_{2}$.

There are other formulations on how to solve this particular problem, which is known in the literature as a frontal analysis problem. Noniterative methods of solution have been developed to describe the process by Claesson. 29

\section{EXPERIMENTS}

\subsection{Experimental Goals}

A series of experiments was designed to investigate the feasibility of separating krypton from $\mathrm{CO}_{2}$ with molecular sieves. These experiments had three goals:

1. To experimentally verify that the process is workable.

2. To obtain sufficient information to enable design of a full-scale system. The information would be sufficient to design a system with conservative design margins but not sufficient for a highly optimized design with only small design margins.

3. To investigate the effects of gaseous components such as xenon and oxygen on system performance.

\subsection{Conceptual Experimental Design}

This experiment consisted basically of measuring the composition, pressure, temperature, and flow rate of the gases entering and leaving 
a single molecular sieve bed as a function of time. Figure 4.1 shows the basic design. The following experimental parameters could be varied: gas composition, type of molecular sieve, gas flow rate, molecular sieve bed temperature, and system pressure.

\subsection{Experimental Design}

The experimental apparatus evolved throughout the experiment, attaining the final configuration described below. Since much of the piping and apparatus was used only for instrument calibration purpnses, the final design appears complex.

\subsubsection{Molecular sieve column}

The design of the molecular sieve column is shown in Fig. 4.2. A narrow column ( $3 / 4$ in.) was initially designed to permit the molecular sieve to be easily kept at a constant temperature and to ensure that any effects of uneven gas distribution across the column would be small. Experiments later showed that the heat generated by the adsorption of $\mathrm{CO}_{2}$ on molecular sieves is so great that a full-scale system must be composed either of many narrow columns placed in a parallel arrangement or fewer, larger columns containing provisions for internal cooling.

\subsubsection{Molecular sieves}

Two types of molecular sieves, $4 A$ and $5 A$, were chosen for evaluation. Their characteristics are summarized in Table 4.1. The choice of molecular sieves was based on best estimates of the materials that were commercially 
$25^{\prime}$

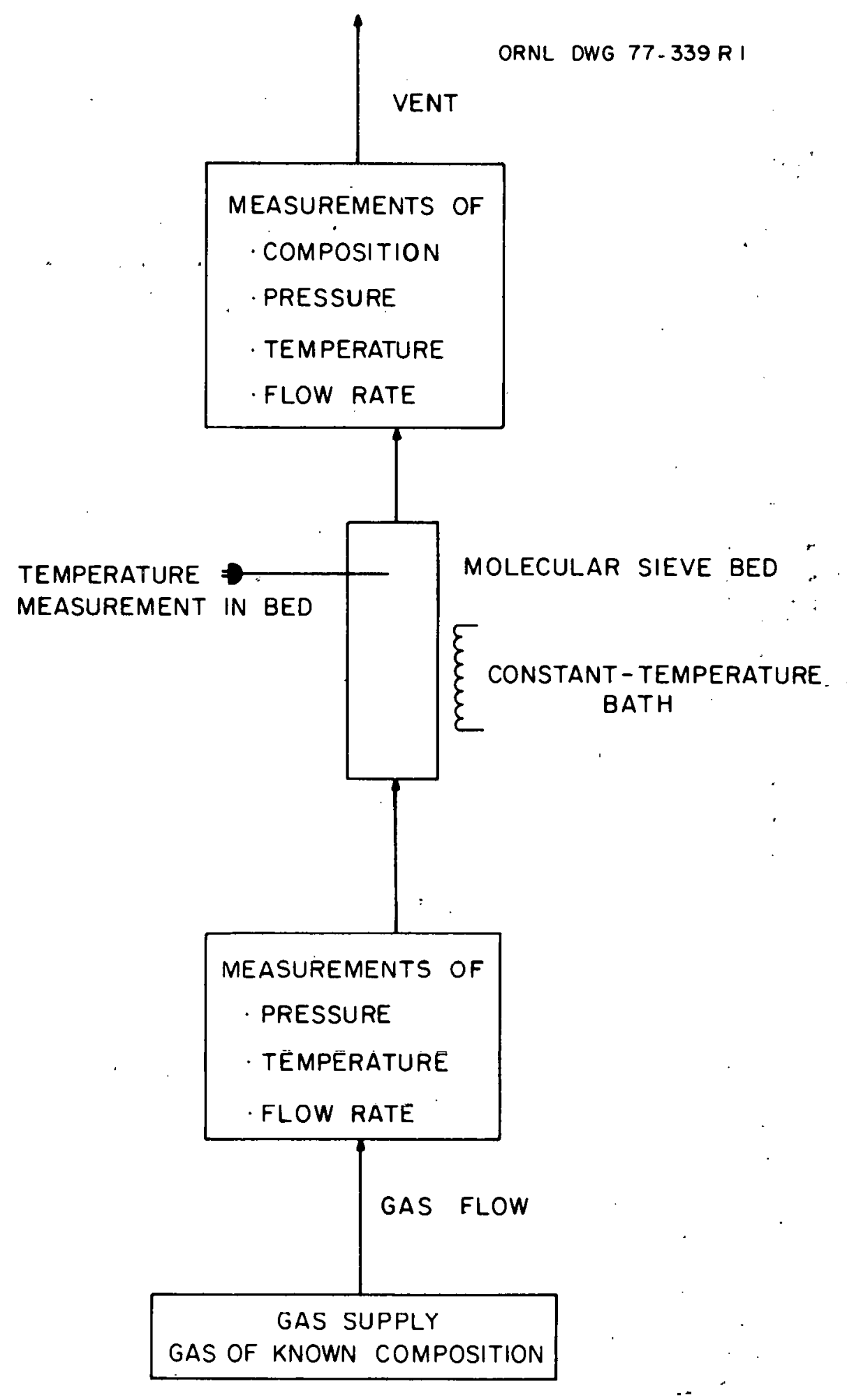

Fig. 4.1. Conceptual experimental design. 


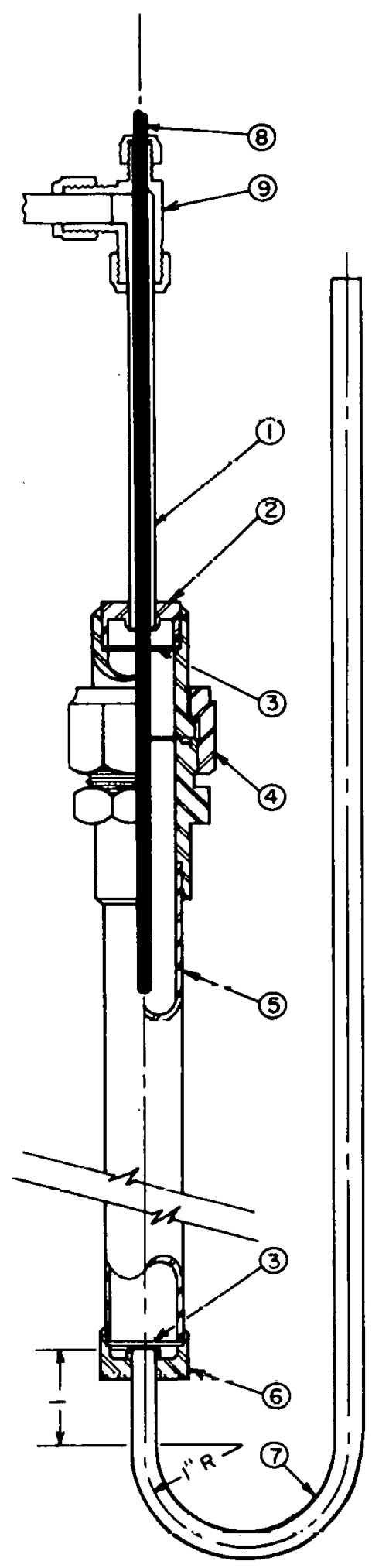

ORNL DWG 77-329 RI

\begin{tabular}{|c|c|}
\hline PART & DESCRIPTION \\
\hline I & $\begin{array}{l}\text { 1/4"O.D. fubing } \times 0.035^{11} W \times 8^{\prime \prime} \cdot \mathrm{Lg}- \\
304 \mathrm{~L} \text { SST. }\end{array}$ \\
\hline 2 & UDDer cop. \\
\hline 3 & 3/4"dio. perforoted disc-316 SST. \\
\hline 4 & $\begin{array}{l}\text { "O" ring vocuum coupling for } 3 / 4 \text { " } \\
\text { fubing, Cojon } 316 \text { SST body with } \\
\text { Viton A "O" ring. }\end{array}$ \\
\hline 5 & $\begin{array}{l}\text { 3/4"O.D. tubing } \times 0.065^{\prime \prime} W \times 36 " \text { L }- \\
304 \text { L 39T. }\end{array}$ \\
\hline 6 & Luwer cup. \\
\hline 7 & $\begin{array}{l}\text { I/4"0.0 tubing } \times 0.035^{\prime \prime} W \times 52^{\prime \prime} \mathrm{Lg}- \\
304 \mathrm{~L} \text { SST }\end{array}$ \\
\hline 8 & 1/8" U.0. copper constantan thermocouple. \\
\hline 9 & Thermocouple tee - $304 \mathrm{~L}$ SST. \\
\hline
\end{tabular}

Fig. 4.2. Molecular sieve column. 
Table 4.1. Characteristics of molecular sieves used

\begin{tabular}{|c|c|c|}
\hline & \multicolumn{2}{|c|}{ Type of molecular sieve } \\
\hline & $4 A^{2}$ & $5 A^{a}$ \\
\hline Manufacturer. & $\begin{array}{l}\text { Union Carbide Corporation, } \\
\text { Linde Division }\end{array}$ & $\begin{array}{l}\text { Union Carbide Corporation, } \\
\text { Linde Division }\end{array}$ \\
\hline Form & Beads & 1/16-in. pellets, $23 / 16$ in. long \\
\hline Composition & $\begin{array}{l}\text { Sodium form of aluminosilicate } \\
\text { crystals, Type A }\end{array}$ & $\begin{array}{l}\text { Calcium form of aluminosilicate } \\
\text { crystals, Type A }\end{array}$ \\
\hline Anālysis & $\begin{array}{l}\text { 280\% active crystalline material, } \\
220 \% \text { inert clay binder }\end{array}$ & $\begin{array}{l}280 \% \text { active crystalline material, } \\
\sim 20 \% \text { inert clay binder }\end{array}$ \\
\hline Density (buik) & $42 \mathrm{lb} / \mathrm{ft}^{3}$ & $40 \mathrm{lb} / \mathrm{ft}^{3}$ (minimum) \\
\hline Heat of adsorption for krypton & & $3720 \mathrm{cal} / \mathrm{mole} \mathrm{e}^{\mathrm{b}}$ \\
\hline Heat of adsorption for $\mathrm{H}_{2} \mathrm{O}$ & - & $18,000 \mathrm{cal} / \mathrm{mole}$ (maximum) \\
\hline
\end{tabular}

${ }^{a}$ Commercially produced form.

bata taken from ref. 19. 
available and applicable for use in a full-scale system. The physical form of the molecular sieve is important because it partially determines mass transfer rates and system pressure drops.

\subsubsection{Experimental flowsheet}

Figure 4.3 shows the flowsheet of the experimental apparatus. The dark line indicates the gas flow during a normal experimental run. All piping was constructed of $1 / 4-i n, 316$ stainless steel tubing with $0.035=$ in.-thick wall. Gas sample lines to the mass spectrometer and some pressure gauges were constructed of 1/16-in. 316 stainless steel capillary tubing with an internal diameter of $0.030 \mathrm{in}$. Whitney valves with compression fittings (Swagelok) were used throughout. In-line heating and cooling coils were made by coiling the tubing and placing it in a constant-temperature bath.

The constant-temperature bath for the molecular sieve consisted of a 4-ft section of 8-in. pipe with a flat plate welded on one end. Calrod heaters were bent around the pipe and secured to the pipc. The molecular sieve bed was located in the center of the bath (pipe), and insulation was placed around the bath. For experiments at temperatures below $100^{\circ} \mathrm{C}$, the bath was filled with water; for those at. $0^{\circ} \mathrm{F}$, it was filled with ice and water. An air bath is used for experiments above $100^{\circ} \mathrm{C}$. The constant-temperaturc bath contained several thernocuuples and thermometers. Constant temperature was maintained by manually adjusting the rheostat, which provided power for the Calrod heaters. 


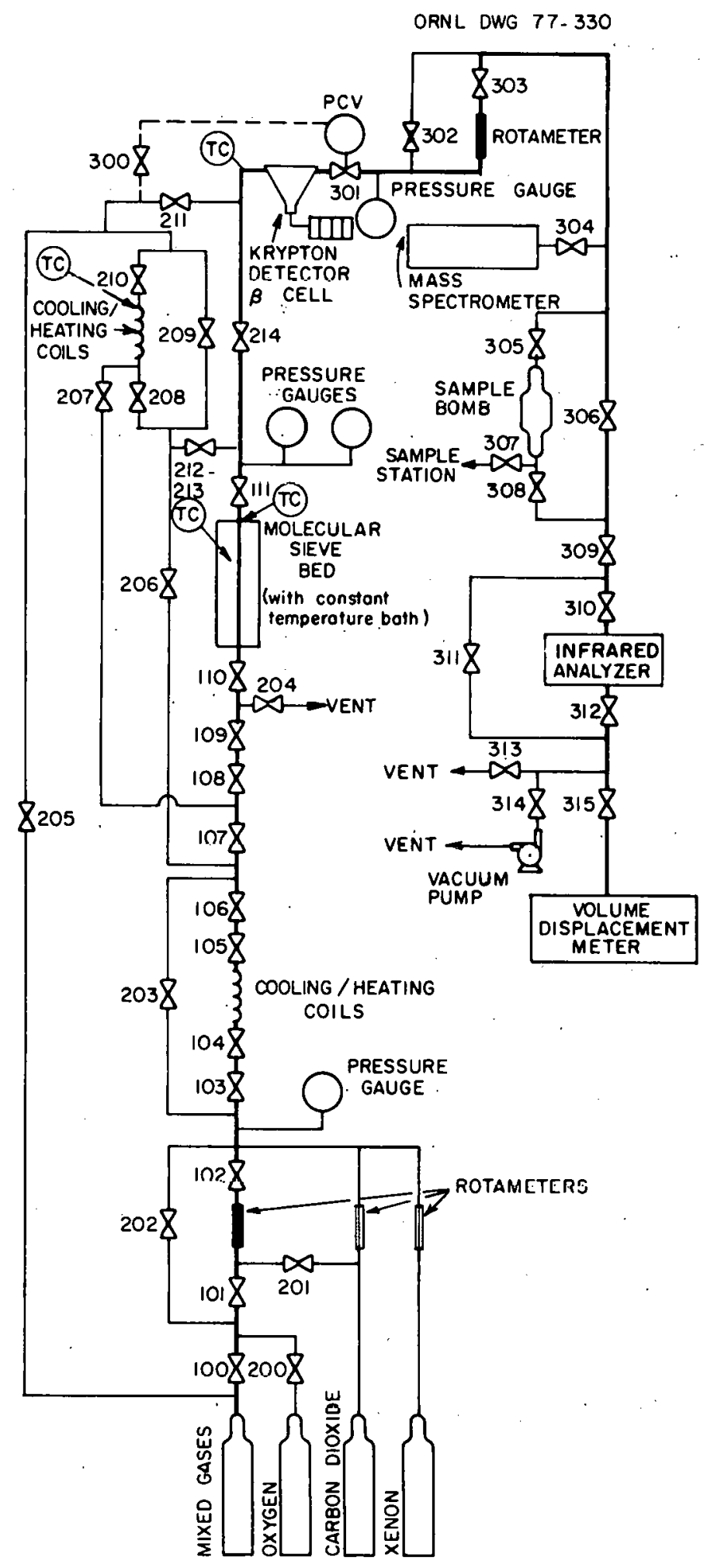

Fig. 4.3. Flowsheet of the experimental apparatus used in molecular sieve study. 


\subsubsection{Instrumentation}

Various instruments and techniques were used to obtain the data from each experiment. The primary instruments are described below.

The composition of the inlet gas was determined by mixing various quantities of pure gases. In most experiments, a gas mixture of the composition $93.09 \% \mathrm{CO}_{2}, 5.43 \% \mathrm{O}_{2}$, and $1.48 \%$ krypton, contained in a single cylinder, was used as the feed gas. The individual gases used in preparing this mixture were specified to be of high purity with very low water concentrations. The final product was analyzed repeatedly over a period of several weeks by several different techniques. Thus this particular gas composition was considered as a known quantity in the various experiments.

Gas flow rates were measured with standard laboratory rotameters which were calibrated with a volume displacement meter. These rotameters had a range of about 0 to $150 \mathrm{cc}$ per minute at standard conditions of temperature and pressure.

System pressure was measured with various pressure gauges having a range from $-15 \mathrm{in}$. $\mathrm{Hg}$ to $60 \mathrm{psig.} \mathrm{(System} \mathrm{pressure} \mathrm{could} \mathrm{be} \mathrm{varied}$ over this entire range.) The system had a vacuum pump for low pressures, while high pressures were obtained via the feed gas cylinders. The pressure was regulated via a pressure control valve (Model 75B, Research Controls, Inc.) with a Foxboro controller.

Temperature measurements throughout the system were made with copper constantan thermocouples and recorded on a 12-point temperature recorder with a temperature range of -50 to $200^{\circ} \mathrm{C}$. The temperature 
of the constant-temperature bath was controlled manually via rheostats that supplied the power to various Calrod heaters.

The measurement of the volume of gas exiting the molecular sieve bed during an experiment, as well as the calibration of rotameters, was achieved with a Vol-u-Meter. ${ }^{*}$ This is a standard volume displacement meter, which consists of a clear tube and a piston with mercury seals.

The krypton in the feed gas was spiked with ${ }^{85} \mathrm{Kr}$, a radionuclide which emits beta rays. Since ${ }^{85} \mathrm{Kr}$ has a half-life greater than 10 years, no corrections for its decay needed to be made during an experimental run. The krypton gas concentrations as a function of time were then measured with a beta-radiation cell and counter. This counter was designed to measure ${ }^{85} \mathrm{Kr}$ in the KALC ${ }^{34}$ process. At a constant temperature and pressure, a doubling of the radiation count rate after correction for background count rate and instrument dead time implies that the concentration of krypton has doubled. After calibration with the standard feed gas, this detector gave very accurate krypton gas analyses. The measurements of the percentage of krypton in the gas streams as a function of time made with this system are believed to be the most accurate analyses performed during experimental runs. Carbon dioxide concentrations were measured with a Beckman Model IR 315 infrared analyzer. Because of range limitations, this instrument

\footnotetext{
*Manufactured by the Brooks Instrument Co.
} 
was used only to measure low concentrations of $\mathrm{CO}_{2}$. With proper calibration, it can measure levels as low as $10 \mathrm{ppm}$.

All other on-1ine gas analyses were conducted with a UTi Model 100 C Precision Mass Analyzer.* This mass spectrometer was used primarily for xenon analysis and to verify that no gas impurities leaked into the system.

\subsection{Experimental Work}

\subsubsection{Experiments with Linde 4A molecular sieve}

Linde $4 \mathrm{~A}$ molecular sieve was used in the first series of scoping experiments. Not all the instrumentation was fully operational during these experiments, nor were the techniques fully developed; hence the accuracy of the raw data is somewhat less than in later experiments. Only a few experiments were done with Linde $4 \mathrm{~A}$ molecular sieve because scoping studies with Linde $5 \mathrm{~A}$ molecular sieve gave better results.

Figure 4.4 plots the krypton concentration of the gas leaving the Linde $4 \mathrm{~A}$ molecular sieve bed as a function of time for three experimental runs. In each case, a constant flow of feed gas was fed to a molecular sieve in a $0^{\circ} \mathrm{C}$ ice bath. The conditions for these experiments are detailed in Table 4.2, while some of the calculated results are listed in Table 4.3.

Three conclusions were drawn from the experimental data:

1. Linde $4 \mathrm{~A}$ molecular sieves adsorb $\mathrm{CO}_{2}$ but do not adsorb significant amounts of krypton or $\mathrm{O}_{2}$. Total removal of $\mathrm{CO}_{2}$ from a feed

\footnotetext{
*Built by Technology International, Sunneyvale, Calif.
} 


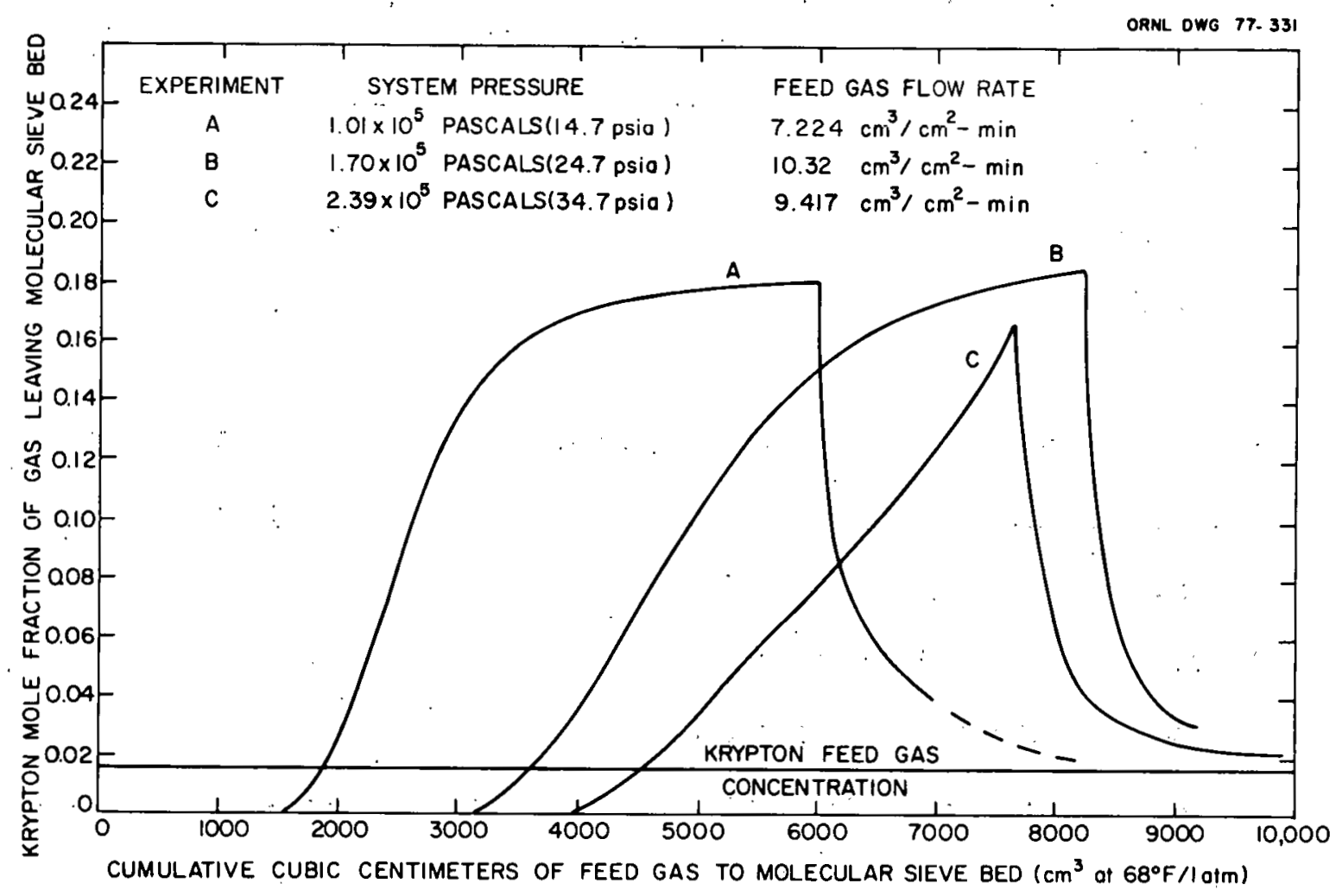

Fig. 4.4. Krypton content of gas leaving $4 \mathrm{~A}$ molecular sieve bed vs cumulative volume of feed gas admitted to molecular sieve bed. 
Table 4.2. Constant parameters in experiments with $4 \mathrm{~A}$ molecular sieve

Feed gas analysis

$\mathrm{CO}_{2}, \%$

$0_{2}, \%$

5.43

$\mathrm{kr}, \%$

1.48

Average molecular wt. of feed gas, g/mole

43.93744

Type of molecular sieve

Linde $4 A$ beads

Molecular sieve temperature, ${ }^{\circ} \mathrm{C}$

0

Molecular sieve bed cross section, $\mathrm{cm}^{2}$

1.94778

Molecular sieve bed inside diameter, $\mathrm{cm}$

1.57 (0.62 in.)

Molecular sieve bed length, cm

$94.62(37.25 \mathrm{ln}$.

Weight of molecular sieve (dry), g

131.5 
Table 4.3. Experimental results using Linde $4 \mathrm{~A}$ molecular sieves

\begin{tabular}{|c|c|c|c|}
\hline Parameter & Expt. A & Expt. B & Expt. C \\
\hline Bed temperature, ${ }^{\circ} \mathrm{C}$ & 0.0 & 0.0 & 0.0 \\
\hline $\begin{array}{l}\text { Bed pressure, } 10^{5} \mathrm{~Pa} \\
\quad(\text { psia) }\end{array}$ & $\begin{array}{r}1.01 \\
(14.7)\end{array}$ & $\begin{array}{r}1.70 \\
(24.7)\end{array}$ & $\begin{array}{r}2.39 \\
(34.7)\end{array}$ \\
\hline $\begin{array}{l}\text { Feed gas flow rate/unit bed area, } \\
\mathrm{cm}^{3}(\mathrm{STP}) / \mathrm{cm}^{2}-\text { min } \\
\left(\mathrm{g} / \mathrm{cm}^{2}-\mathrm{min}\right)\end{array}$ & $\begin{array}{l}7.224 \\
(0.01416)\end{array}$ & $\begin{array}{l}10.32 \\
(0.020234)\end{array}$ & $\begin{array}{l}9.417 \\
(0.01846)\end{array}$ \\
\hline $\begin{array}{l}\text { Length of mass transfer zone, } \\
0_{2} \text { peak to krypton peak, cm }\end{array}$ & 21.7 & 30.97 & $--b$ \\
\hline $\begin{array}{l}\text { Length of mass transfer zone, } \\
\text { krypton peak to feed peak, } \mathrm{cm}\end{array}$ & 11.8 & 4.3 & $--b$ \\
\hline
\end{tabular}

${ }^{a}$ The length of the mass transfer zone is defined as the minimum distance through the bed where the concentration of krypton changes by $80 \%$ of the difference between one quasi-steady-state concentration of krypton exiting the bed and another quasi-steady-state concentration of krypton exiting the bed.

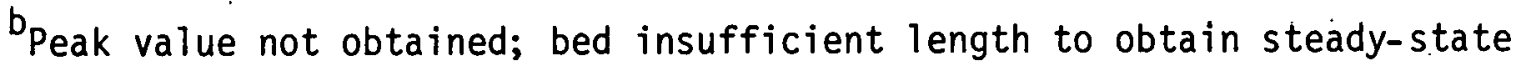
krypton-oxygen gas composition. 
gas composed of $93.09 \% \mathrm{CO}_{2}, 5.43 \% \mathrm{O}_{2}$, and $1.48 \%$ krypton yields a gas containing $21.4 \%$ krypton and $78.7 \% \mathrm{O}_{2}$. The maximum krypton concentration obtained, as shown in Fig. 4.4, is about $20 \%$ (i.e., the concentration of krypton expected if only $\mathrm{CO}_{2}$ is adsorbed).

2. The optimum operating pressure for molecular sieves is near $10^{5}$ $\mathrm{Pa}(14.7 \mathrm{psia})$ for operating temperatures in the vicinity of $0^{\circ} \mathrm{C}$. The operating pressures for this series of experiments varied from $1.01 \times 10^{5} \mathrm{~Pa}(14.7 \mathrm{psia})$ in experiment $\mathrm{A}$ to $2.39 \times 10^{5} \mathrm{~Pa}(34.7$ psia) in experiment $C$. As the results of these experiments show, in the delay of the krypton breakthrough at higher pressures, the advantage of higher operating pressures is that the molecular sieve can adsorb more $\mathrm{CO}_{2}$. Unfortunately, the molecular sieve begins to saturate in $\mathrm{CO}_{2}$ slightly above $1 \mathrm{~atm}$, with less and less $\mathrm{CO}_{2}$ being adsorbed for each increase in system pressure. This single advantage of high system pressure is outweighed by three disadvantages. Two of these are associated with all molecular sieves, whereas the third is specific to $4 \mathrm{~A}$ molecular sieves.

(a) As system pressure increases, the width of the krypton peak leaving the molecular sieve bed (see Fig. 4.4) decreases. The total amount of krypton leaving the bed is about the same in each experiment; however, at higher pressures, the krypton gas volume is less. At the high pressure used in experiment $C$, the volume of krypton generated in about $1 \mathrm{~m}$ of bed is insufficient to allow the peak krypton concentration to be attained. Removal of the krypton from the gas flow as it leaves the bed is desirable so that it can be sent to a 
bottling station. High pressure narrows the peak and thereby increases the difficulty of removing krypton alone; hence high pressure should be avoided.

(b) As the system pressure increases, proportionally more of the. gas is present in the gas phase between the molecular sieve particles than is adsorbed by the molecular sieve (because molecular sieve adsorption levels off). As shown earlier in Fig. 2.2, a large amount of krypton present in the feed gas in the void space between particles cannot be separated from the $\mathrm{CO}_{2}$. The problem is intensified as the pressure increases.

(c) At high system pressures, $4 \mathrm{~A}$ molecular sieves can begin to adsorb krypton but the kinetics of krypton adsorption and desorption are so slow that practical system designs are not possible.

3. The kinetics of $\mathrm{CO}_{2}$ adsorption by Linde $4 \mathrm{~A}$ molecular sieve, al though reasonably fast, are, as shown later, relatively slow compared with alternative molecular sieves such as $5 \mathrm{~A}$. Table 4.3 gives the length of the mass transfer zone between the $\mathrm{CO}_{2}$ and the krypton. (The mass transfer zone is defined as that minimum length through the molecular sieve bed where the concentration of krypton varies by $80 \%$ of the difference between the peak krypton concentration in the bed and the krypton concentration in the feed.) The measured mass transfer length is as high as tens of centimeters. The mass transfer length for $5 \mathrm{~A}$ molecular sieves, on the other hand, does not exceed a few centimeters, implying much faster mass transfer. 


\subsubsection{Series $A$ experiments with Linde $5 A$ molecular sieve}

Linde $5 \mathrm{~A}$ molecular sieve strongly adsorbs $\mathrm{CO}_{2}$ and weakly adsorbs krypton; however, it does not adsorb $0_{2}$ significantly. Consequently, when a feed gas composed of $93.09 \% \mathrm{CO}_{2}, 5.43 \% \mathrm{O}_{2}$, and $1.48 \%$ krypton is fed to $5 \mathrm{~A}$ molecular sieve, it is separated into $\mathrm{CO}_{2}$, krypton, and $\mathrm{O}_{2}$. Figure 4.5 shows the results of a typical experimental run. The separation of the various gases is sharp, in contrast to the experimental results shown in Fig. 4.4 with $4 \mathrm{~A}$ molecular sieve.

The results of ten experimental runs are given in Table 4.4. Throughout these runs, the molecular sieve was kept in a constant-temperature bath at $0^{\circ} \mathrm{C}$. The composition of the feed gas was $93.09 \% \mathrm{CO}_{2}, 5.43 \% .0_{2}$, and $1.48 \%$ krypton with ${ }^{85} \mathrm{Kr}$ tracer. The system pressure was varied from $1.01 \mathrm{x}$ $10^{5} \mathrm{~Pa}(1 \mathrm{~atm})$ to $2.53 \times 10^{5} \mathrm{~Pa}(2.5 \mathrm{~atm})$, while the feed gas flow was varied from $1.494 \times 10^{-2} \mathrm{~g}$ per minute per square centimeter of molecular sieve bed cross section $\left[7.62 \mathrm{~cm}^{3}(\right.$ STP $\left.) / \mathrm{cm}^{2}-\min \right]$ to $29.964 \times 10^{-2} \mathrm{~g} / \mathrm{cm}^{2}$ $\min \left(152.86 \mathrm{~cm}^{3} / \mathrm{cm}^{2}-\min \right)$. When it was desired to strip the molecular sieve of $\mathrm{CO}_{2}$, the bed was heated to at least $150^{\circ} \mathrm{C}$ for $8 \mathrm{hr}$ under vacuum provided by a mechanical vacuum pump and was purged with oxygen several times during bakeout. The following results were obtained:

1. In each run where the bed was carefully desorbed of $\mathrm{CO}_{2}$, the concentrations of $\mathrm{CO}_{2}$ in the oxygen product and in the oxygen-krypton product were below the limit of $\mathrm{CO}_{2}$ detection (10 ppm) by the instrumentation being used.

2. No krypton was detected in the pure oxygen exiting the bed before the krypton. The krypton detector can detect krypton concentrations 
ORNL OWG 76-1021

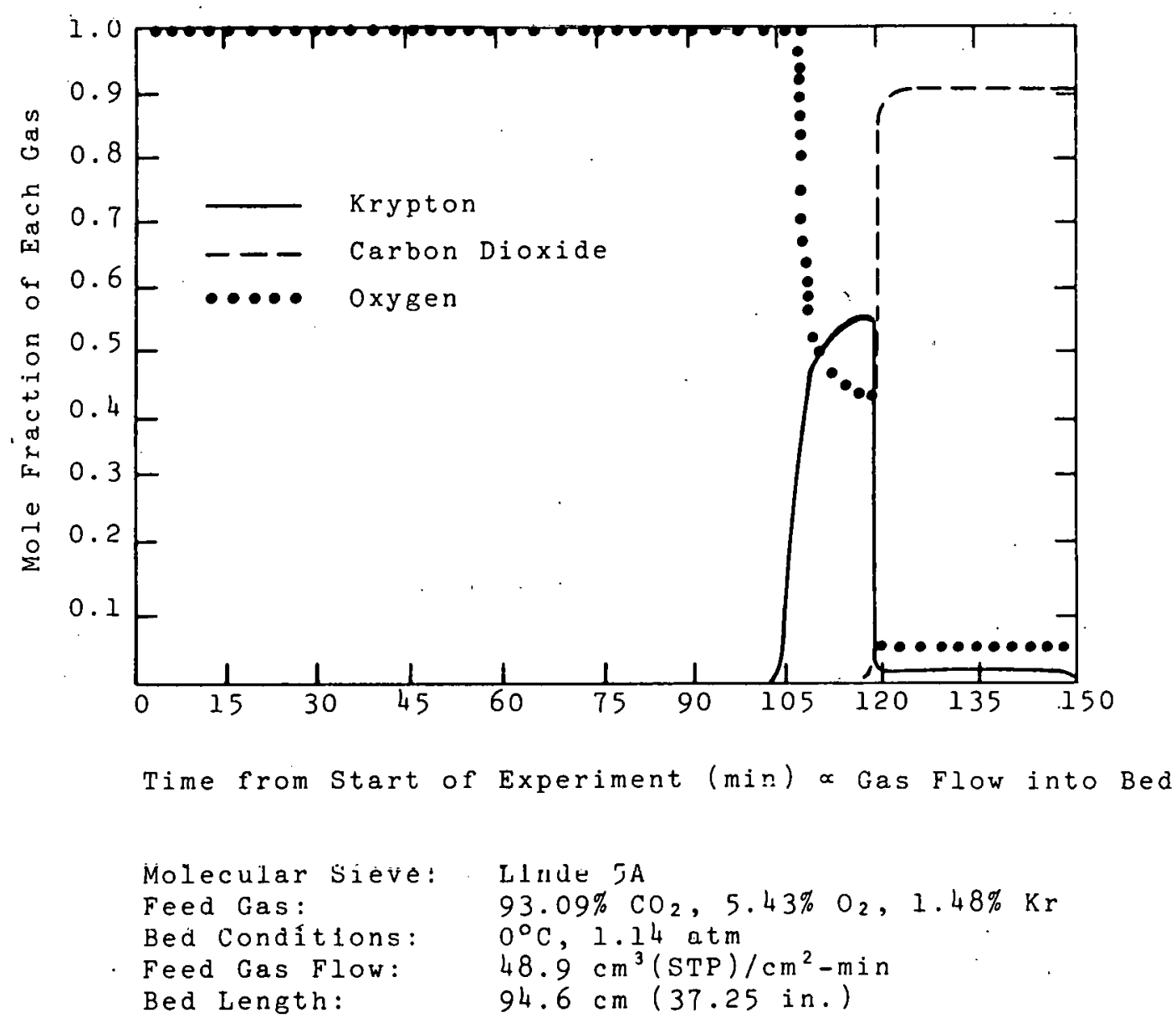

Fig. 4.5 Gas composition from molecular sieve bed vs time. 
Tatle 4.4. Experimental results

\begin{tabular}{|c|c|c|c|c|c|c|}
\hline $\begin{array}{c}\text { Run } \\
\text { number }\end{array}$ & $\begin{array}{c}\text { Pressure } \\
\quad(a t m)\end{array}$ & $\begin{array}{c}\text { Flow rate } \\
\left(\mathrm{cm}^{3} / \mathrm{cm}^{c}-\min \right)^{a}\end{array}$ & $\begin{array}{l}\text { Length of } \\
\text { nass transfer } \\
\text { zone } \\
(\mathrm{cm})\end{array}$ & $\begin{array}{c}\text { Max. krypton } \\
\text { concentration } \\
(\%)\end{array}$ & $\begin{array}{c}\text { Implied temp. } \\
\text { difference } \\
\left({ }^{\circ} \mathrm{C}\right)\end{array}$ & $\begin{array}{c}\mathrm{CO}_{2} \\
\text { adsorbed } \\
\left(\mathrm{cm}^{3} / \mathrm{g}\right)^{\mathrm{b}}\end{array}$ \\
\hline 1 & 1.0 & 7.6 & 1.0 & 52.3 & 30 & 89.8 \\
\hline 2 & 1.0 & 34.1 & 2.3 & 55.6 & 25 & 93.9 \\
\hline 3 & 1.0 & 49.9 & 1.0 & 58.0 & 21 & 103.5 \\
\hline 4 & 1.0 & 76.2 & 1.4 & 56.2 & 24 & 93.5 \\
\hline 5 & 1.0 & 91.7 & 1.5 & 55.5 & 25 & 99.6 \\
\hline 6 & 1.14 & 48.0 & 1.1 & 58.6 & - & 87.9 \\
\hline 7 & 1.14 & 48.9 & 1.1 & 58.2 & -- & 93.8 \\
\hline 8 & 2.36 & 50.3 & 2.1 & 51.6 & -- & 94.6 \\
\hline 9 & 2.36 & 96.4 & 3.1 & 61.8 & -- & 96.6 \\
\hline 10 & 2.36 & 152.9 & 2.3 & 57.4 & -- & 93.1 \\
\hline
\end{tabular}

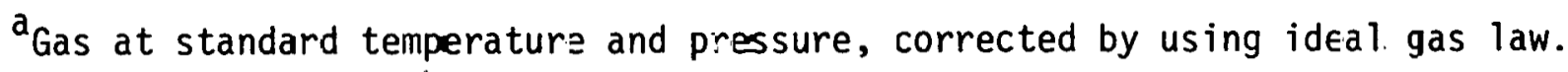

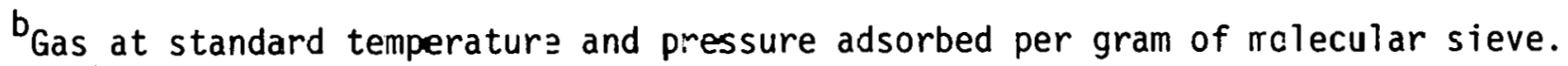


about one-thousandth that of the feed gas; this implies that the krypton concentration in the oxygen is not more than 0.001 the krypton concentration in the feed gas.

3. The mass transfer between $\mathrm{CO}_{2}$, krypton, and the adsorbing surface is very rapid and does not limit the performance of a molecular sieve bed under reasonable operating conditions. Table 4.4 shows the length of the krypton- $\mathrm{CO}_{2}$ mass transfer zone within the molecular sieve bed. The mass transfer length is defined as the minimum distance through the bed where the concentration of krypton changes by $90 \%$ of the difference between the maximum krypton concentration and its value in the feed gas. Note that the length of the mass transfer. zone is only about three times that of the molecular sieve pellets $(0.5 \mathrm{~cm})$. A mass transfer zone, at most a few centimeters long in a bed that is several meters long, does not. limit bed performance or operation. Mass transfer should not be a limiting factor in equipment design or performance.

4. When a feed gas containing $1.48 \%$ krypton was used, the concentrations of krypton in the product streams of all experiments exceeded $50 \%$. This implies total $\mathrm{CO}_{2}$ removal and significant separation of $\mathrm{O}_{2}$ from krypton since the maximum krypton concentration possible by removal of $\mathrm{CO}_{2}$ only is $21.4 \%$. Table 4.4 shows the krypton product concentrations. According to theory, a krypton concentration of $71.5 \%$ would be expected at $0^{\circ} \mathrm{C}$ and 1 atm of pressure with the feed gas previously described. Note that the predicted krypton concentration is higher than the experimentally determined concentration. 
Adsorption of $\mathrm{CO}_{2}$ releases large amounts of heat $(12,500 \mathrm{cal} / \mathrm{mole})$, which results in a decrease in the adsorption of krypton. This decrease, according to the model, results in a decrease in the maximum krypton concentration. As shown in later experiments, the rising internal bed temperature caused this difference between theory and experiment. The column labeled "Implied Temperature Difference" in Table 4.4 shows to what temperature the bed must be heated above $0^{\circ} \mathrm{C}$ in order for the model to fit experimental results. As a point of comparison, the heat of adsorption of the $\mathrm{CO}_{2}$ on the molecular sieve would be sufficient to increase the temperature of the bed to $240^{\circ} \mathrm{C}$ if there was no cooling and if higher temperatures did not desorb $\mathrm{CO}_{2}$ and thereby reverse the heat effects. This temperature effect indicates that the limiting design condition for a molecular sieve bed in the proposed process is the rate at which heat of adsorption can be removed from the bed.

5. The capacity of the molecular sieve to adsorb $\mathrm{CO}_{2}$, using the manufacturer's data, ${ }^{18}$ was found to be $94.2 \mathrm{~cm}^{3} / \mathrm{g}$ for a temperature of $0^{\circ} \mathrm{C}$, a pressure of $1.01 \times 10^{5} \mathrm{~Pa}(1 \mathrm{~atm})$, and a gas composed of $93.09 \% \mathrm{CO}_{2}$. This value agrees with the experimental results presented in Table 4.4. The experimental data show considerable scatter because the amounts of $\mathrm{CO}_{2}$ entering and leaving the experimental apparatus are simply measured by rotameters over a period of several hours, a technique which is not designed to obtain accurate values. At these $\mathrm{CO}_{2}$ partial pressures, the molecullar 
sieve is approaching saturation and small changes in pressure have little effect on the amount of $\mathrm{CO}_{2}$ adsorbed.

6. The preliminary molecular sieve bed desorption runs were made by heating the bed to $150^{\circ} \mathrm{C}$. The results indicate that the $\mathrm{CO}_{2}$ evolved from the bed contained less than one-fiftieth of the krypton that the feed contained. The krypton that is evolved is primarily krypton released from the gas spaces between molecular sieve particles, above the bed, and in the piping. The krypton concentration in the desorbed $\mathrm{CO}_{2}$ can be decreased by minimizing open gas volumes or purging the bed with small amounts of $\mathrm{CO}_{2}$ to displace the krypton-containing feed gases from the gas spaces in the bed.

\subsubsection{Series B experiments with Linde 5 A molecular sieve}

The first series of experiments outlined the basic adsorption characteristics of Linde $5 \mathrm{~A}$ molecular sieve for the proposed process.

This second series was undertaken to address four specific questions:

1. Does the heat of adsorption of the $\mathrm{CO}_{2}$ on a molecular sieve bed present a real design limitation for building full-scale equipment?

2. How does xenon in the feed gas affect the proposed process?

3. How is the proposed process affected by lower-than-expected concentrations of krypton?

4. Are there any problems in desorbing $\mathrm{CO}_{2}$ from the molecular sieve bed?

The apparatus used for this set of experiments was the same as that used in earlier experiments except for two modifications of the molecular 
sieve bed: thermocouples were installed, and the length was doubled by placing two identical beds in series.

The installation of thermocouples revealed that the adsorption of $\mathrm{CO}_{2}$ produces so much heat that even cooling of the narrow $0.75-$ in. $-0 \mathrm{D}$ molecular sieve bed used in these experiments with an ice bath cannot keep its temperature at $0^{\circ} \mathrm{C}$. The corrected temperature and krypton concentration measurements from a single experimental run are plotted in Fig. 4.6. Other experimental parameters and results of this experiment are shown in Table 4.5. The krypton measurements are from a detector downstream of the bed, while the thermocouple is located in a region of the bed near the exit. Two expanded scales show the breakthrough of krypton and $\mathrm{CO}_{2}$ out of the bed. There are two temperature peaks; the smaller peak is from the heat of adsorption of krypton ( $3720 \mathrm{cal} / \mathrm{mole}$ ), while the larger one is from the heat of adsorptinn of $\mathrm{CO}_{2}$. Carbon dioxide heated the center of the bed to nearly $40^{\circ} \mathrm{C}$ before the ice bath recooled the bed back to $0^{\circ} \mathrm{C}$. The large temperature transient of the bed in a constant-temperature bath shows conclusively that the major design limitation will be in finding methods to r.nnl the bed adequately. The large temperature transient also suggests the possibility of determining the location of the $\mathrm{CO}_{2}$ adsorption front in a molecular sieve bed by the use of thermocouples.

A series of experiments was made with xenon added to the standard feed gas. Figure 4.7 shows the results of one of these experiments, whereas Table 4.6 lists the conditions and some of the results of the experiments. Like Fig. 4.6, Fig. 4.7 plots both the temperature of 
ORNL DWG 77.332

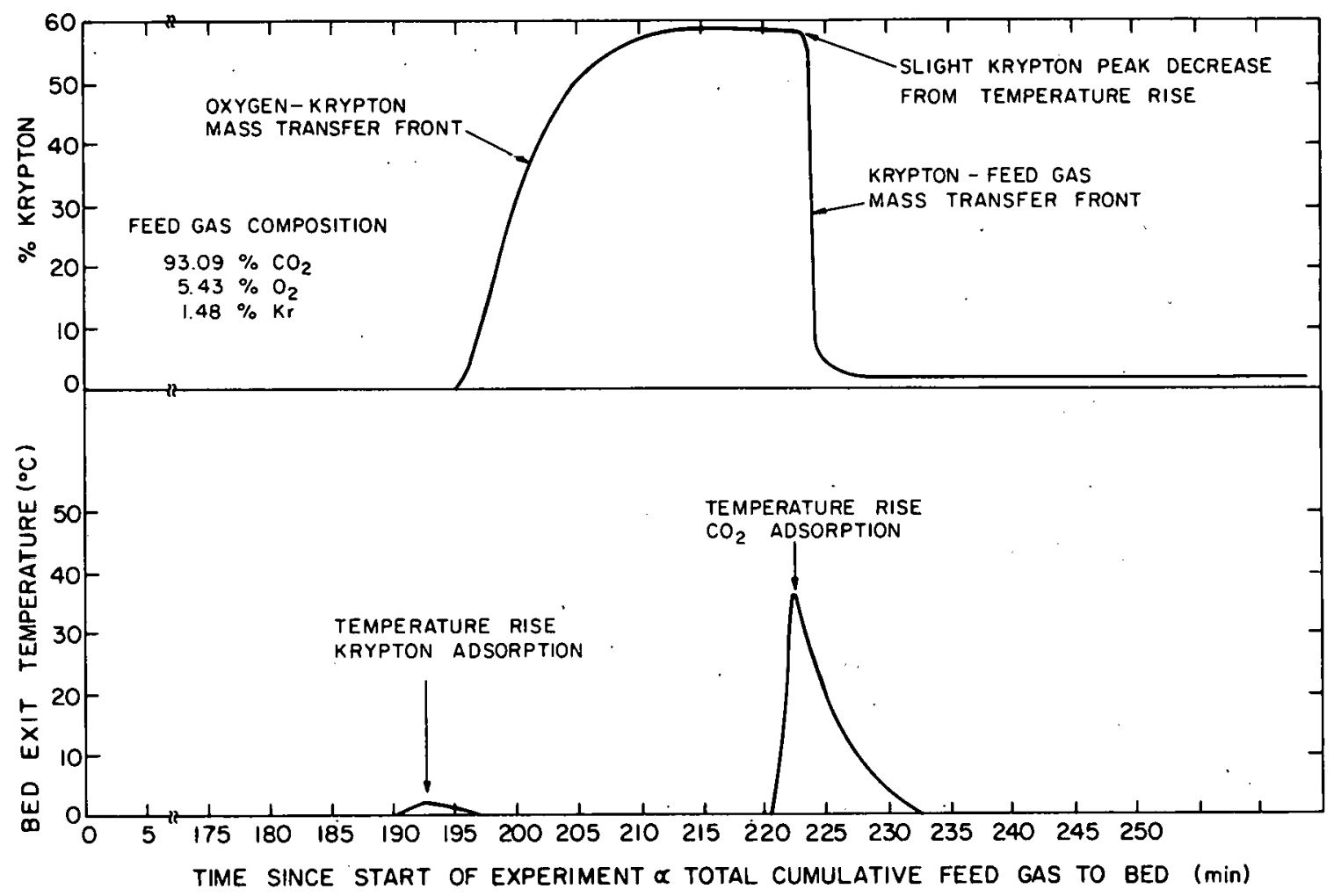

Fig. 4.6. Krypton concentration and molecular-sieve-bed thermocouple readings vs time. 
Table 4.5. Conditions for the experimental data shown in Figure 4.6

\begin{tabular}{lc} 
Type of molecular sieve & $5 \mathrm{~A}$ \\
Feed gas composition, $\%$ & 93.09 \\
$\mathrm{CO}_{2}$ & 5.43 \\
$\mathrm{O}_{2}$ KFypton & 1.48 \\
Bed temperature, ${ }^{\circ} \mathrm{C}$ & 0 \\
Bed pressure, Pa (psia) & $1.10 \times 10^{5}$ \\
& $(15.9)$ \\
Gas flow rate (constant), & 52.58 \\
$\mathrm{~cm} 3 / \mathrm{min}^{2}$-cm ${ }^{2}$ bed (STP) \\
(g/cm² bed-min) & $(0.1031)$ \\
Maximum krypton concentration, $\%$ & 58.5 \\
\hline
\end{tabular}


ORNL OWG $77.333 \mathrm{RI}$

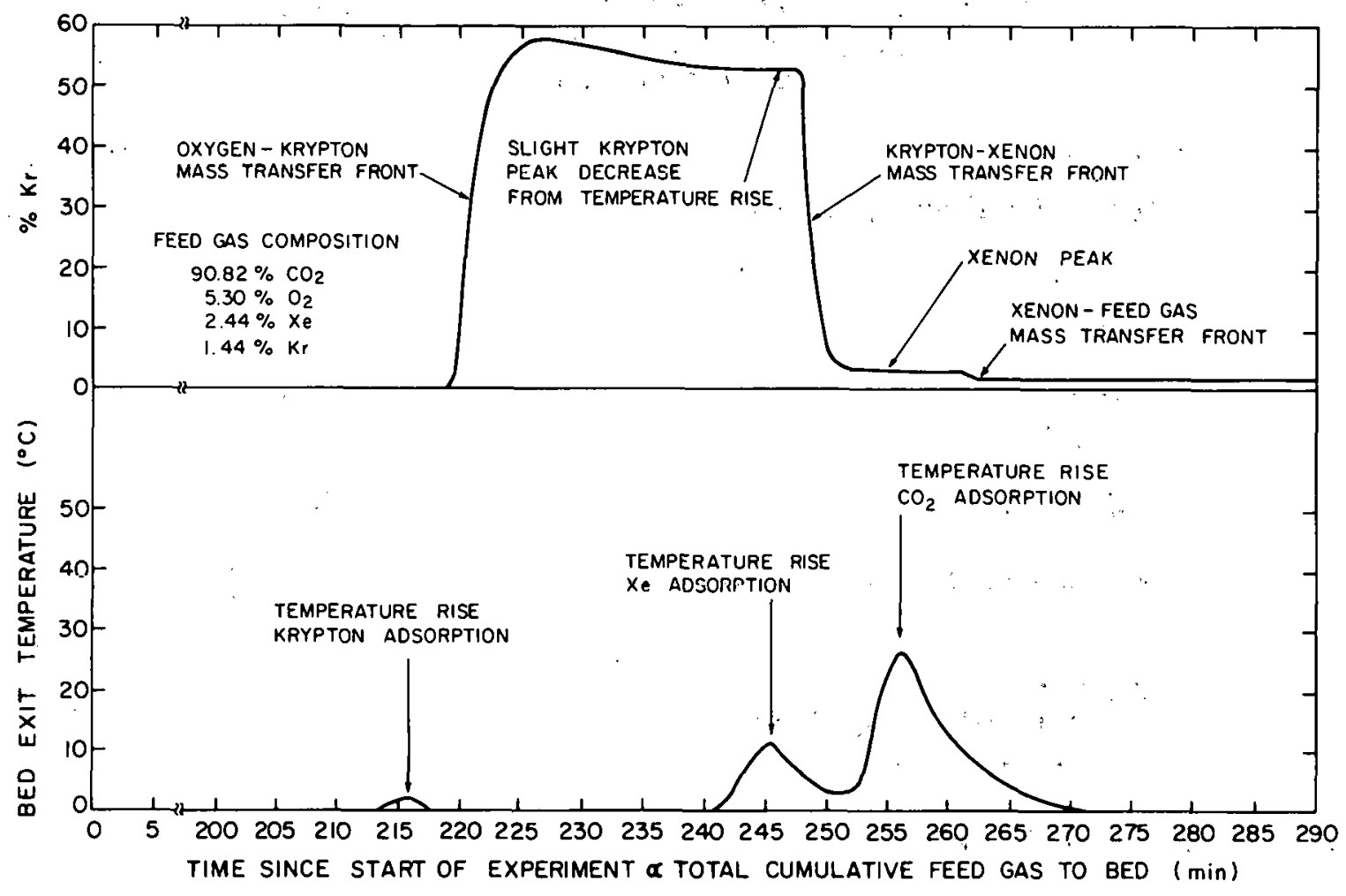

Fig. 4.7. Krypton concentration and molecular-sieve-bed thermocouple readings vs time. 
Table 4.6. Conditions and selected results of experiments made with feed gas containing xenon

\begin{tabular}{lc} 
Type of molecular sieve & $5 \mathrm{~A}$ \\
Fccd gas composition, $\%$ & 90.82 \\
$\mathrm{CO}_{2}$ & 5.30 \\
$0_{2}{ }^{2}$ enon & 2.44 \\
Krypton & 1.44 \\
Bed temperature, ${ }^{\circ} \mathrm{C}$ & 0 \\
Bed pressure, Pa (psia) & $1.01 \times 10^{5}$ \\
& $(14.7)$ \\
Gas flow rate, & 53.0 \\
cm ${ }^{3}$ (STP) min-cm ${ }^{2}$ bed & \\
cross section & 57.54 \\
Maxtmum krypton concentration, $\%$ & 67.0 \\
Maximum xenon concentration, $\%$ & \\
\hline
\end{tabular}


the molecular sieve near the exit of the bed and the krypton gas concentration exiting the bed as a function of time since the experiment started. The experiment had a constant flow of feed gas; hence the time since the start of the experiment is proportional to the cumulative feed gas admitted to the bed. The following observations were made about xenon:

1. The xenon gas concentrates between the krypton gas peak and the feed gas as detected by the mass spectrometer.

2. Adsorption of xenon on the $5 \mathrm{~A}$ molecular sieve produces heat ${ }^{19}$ (5250 cal/mole), which causes a significant rise in bed temperatures (Fig. 4.7).

3. The xenon does not appear to totally displace all krypton, as seen by the higher-than-feed concentration of krypton in the xenon gas between the krypton gas peak and the feed gas.

4. The peak xenon gas concentration measured was $67 \%$. However,' this value has a very large degree of uncertainty associated with it because of mass spectrometer calibration problems, very long sample lines to the spectrometer, and the semibatch analysis by the spectrometer for xenon.

5. Xenon does not significantly affect the product concentration of krypton.

6. The $\mathrm{CO}_{2}$ content of the concentrated xenon exiting the molecular sieve bed is below $10 \mathrm{ppm} ; 10 \mathrm{ppm}$ was the lowest concentration detectable with the instrumentation used.

Several experiments were conducted using a feed gas low in krypton to observe the effect of varying gas compositions. The only major 
result of these experiments was to narrow the width of the krypton peak leaving the molecular sieve bed. Figure 4.8 shows the results of a typical run. In this particular case, the krypton content in the feed was insufficient to produce a peak krypton concentration $>41 \%$. Variations of krypton concentrations in the feed gas should not affect system operation or performance.

A set of experiments was conducted to determine whether any problems existed in desorbing $\mathrm{CO}_{2}$ from Linde $5 \mathrm{~A}$ molecular sieve by heating the bed to $200^{\circ} \mathrm{C}$. None was found. In some experiments, the heating rate $\left(70^{\circ} \mathrm{C} / \mathrm{hr}\right)$ was sufficient to cause a pressure rise in the bed because $\mathrm{CO}_{2}$ could not escape fast enough through the piping network. In any design work where a fast desorption cycle by heating is used, the rate of gas evolution should be calculated to ensure sufficient piping size.

In most experiments, the bed was heated to $200^{\circ} \mathrm{C}$, the $\mathrm{CO}_{2}$ was driven off, and oxygen was allowed to flow over the exit of the bed. The bed was then cooled from the bottom to allow any residual $\mathrm{CO}_{2}$ to adsorb onto the portion of the bed near the gas feed point. 0xygen blanketed the bed as the $\mathrm{CO}_{2}$ was adsorbed. In such cases, no problems were seen in the adsorption part of the cycle. For example, Fig. 4.5 shows an adsorption cycle where the above procedure was used with no difficulty. Any real design problems with desorption are likely to be related to heat transfer. 
ORNL DWG 77.334

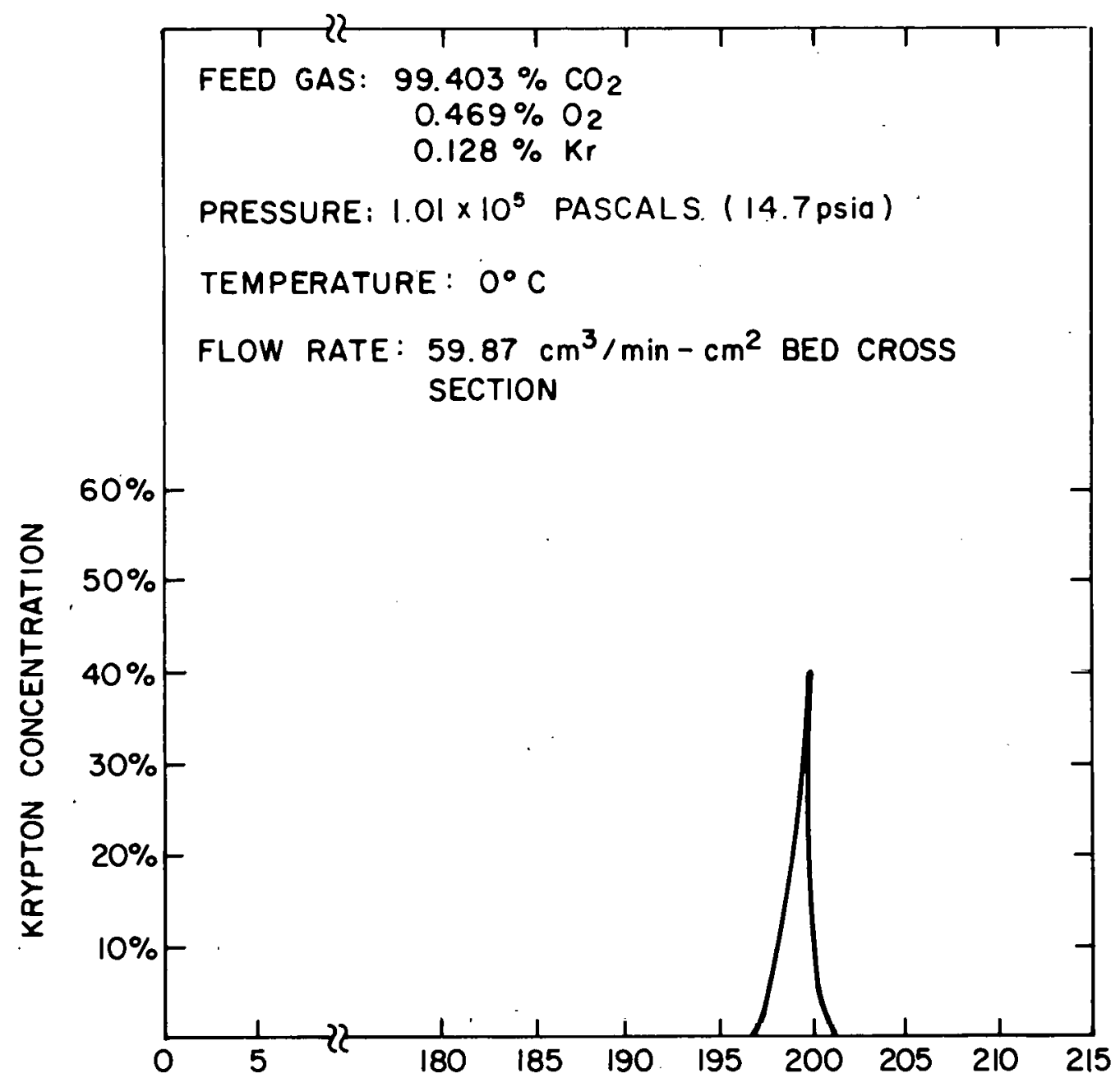

TIME FROM START OF EXPERIMENT $\propto$ CUMULATIVE- FEED GAS FLOW(min)

Fig. 4.8. Krypton gas concentration exiting the molecular sieve bed vs time. 


\section{DESIGN CONSIDERATIONS AND RECOMMENDATIONS}

\subsection{Design Recommendations}

The results of the experiments and analyses conducted, along with the preliminary flowsheets of the full-scale off-gas system, 35,36 allow four recommendations for design to be made:

1. Linde 5A molecular sieve, or the equivalent, should be used for separating krypton and $\mathrm{CO}_{2}$ because it only slightly adsorbs krypton but strongly adsorbs $\mathrm{CO}_{2}$. This is desirable for the following reasons:

(a) The krypton will separate from lighter gases. Some types of plant upset conditions result in large quantities of light gases. The proper choice of molecular sieve eliminates this problem.

(b) Slight krypton adsorption provides a sharp separation between $\mathrm{O}_{2}$ and k.rypton fronts and krypton and $\mathrm{CO}_{2}$ gas fronts. Such a separation makes location of the gas front by either thermocouple or radiation detection instruments easier due to the slpurig temperature and gas gradients in the bed.

(c) Higher krypton concentrations can be obtained.

2. The molecular sieve columns should be arranged so that all of the gas zones leaving one column enter directly into the next column; with such an arrangement, the column has infinite length from the standpoint of the gases. The oxygen, krypton, and other gases can be withdrawn in the piping between beds, simply narrowing the width of the respective gas zone as it passes between beds. This 
approach is desirable if there is a low krypton concentration. The krypton gas zone can be cycled through several columns, building up the length of the krypton gas zone until it is easy, by valving, to remove only the krypton gas without $\mathrm{O}_{2}$ or $\mathrm{CO}_{2}^{\prime}$. Processes such as those described in Fig. 2.2, while feasible, should be avoided if high krypton concentrations are desired.

3. The major design constraint is cooling the molecular sieve bed. As discussed earlier, the adsorption of $\mathrm{CO}_{2}$ releases very large quantities of heat. In addition, in actual facilities, the krypton may contain up to $6 \%{ }^{85} \mathrm{Kr}$. The decay of this radioactive isotope will provide a very high heat load. Any design must recognize that most of this heat is being dumped into the small krypton gas zone and the nearby $\mathrm{CO}_{2}$ adsorption zone; consequently, heat transfer calculations must be based on the active zone instead of the whole bed. It is recommended that the bed be designed very similar to a vertical tube-and-shell heat exchanger. No molecular sieve in the bed can probably be more than a few centimeters from the heat transfer surface.

4. The cross-sectional area of the bed depends on the gas velocity in the bed. A reasonable range of gas velocities is from 50 to 100 $\mathrm{cm}^{3} / \mathrm{min}-\mathrm{cm}^{2}$ of bed cross section. Slower gas velocities increase the bed size. Faster gas velocities cause excessive pressure drops and create cooling problems. Molecular sieve manufacturers 37 provide correlations to calculate pressure drop. If bed cooling is insufficient, the temperature rises and krypton adsorption decreases, resultiny in a decrease in krypton concentrations. 


\subsection{System Design and Sizing}

No effort was made to prepare a detailed design for a krypton- $\mathrm{CO}_{2}$ separation system placed after KALC for a full-scale plant for reprocessing HTGR fuel elements. A preliminary design was made using the assumptions listed in Table 5.1 and the process flowsheet shown in Fig. 2.3. The results of this design are listed in Table 5.2. The most important conclusion obtained is that the actual system could be built with three molecular sieve columns $20 \mathrm{in}$. in diameter and $8 \mathrm{ft}$ long. Careful design and process modification could probably reduce the size of the system by one-half.

\subsection{Alternative Uses for the $\mathrm{CO}_{2}$-Krypton Separation System}

The experiments performed to date indicate that this molecular sieve system can separate krypton from $\mathrm{CO}_{2}$ at almost any krypton concentration. It is therefore reasonable to ask if the KALC system could be replaced with this system. While technically feasible, the preliminary evidence suggests that this would be uneconomical for two reasons:

1. If the molecular sieve columns were sized for a full-scale plant to replace KALC, using the assumptions of Table 5.1, each column would have a diameter of $50 \mathrm{ft}$. Although careful design and engineering could greatly reduce this size, the volume of the equipment would still be large. Since the off-gas contains radioactive ${ }^{85} \mathrm{Kr}$, the system would contain a large inventory of ${ }^{85} \mathrm{Kr}$. Radiation shielding requirements and rcquirements to protect equipment against external damage imply thick, reinforced concrete walls. The cost of containment structures around the 
Table 5.1. Assumptions used in preliminary design of krypton- $\mathrm{CO}_{2}$ separation system using molecular sieves

Plant capacity

Plant operating schedule

Total system off-gas flow/HTGR

fuel block

off-gas composition

Type of molecular sieve

$\mathrm{CO}_{2}$ adsorption $\left(200-0^{\circ} \mathrm{C}\right)$

$\mathrm{CO}_{2}$ heat of adsorption/desorption

Density of molecular sieve

Heat capacity of molecular sieve

Heat of adsorption of other gases, heat leakage, krypton heating, other losses

Bed pressure

Bed adsorption temperature

Bed desorption temperature

Bed heat capacity (internal)
50,000 HTGR fuel blocks/year [50 GW(e) equivalent]

300 days/year

$4.5 \times 10^{8} \mathrm{~cm}^{3}\left(1.6 \times 10^{4} \mathrm{scf}\right)$

$\mathrm{CO}_{2}: \quad 95 \%$

$\mathrm{Kr}: \quad 15 \mathrm{ppm}$

Other: $5 \%$

Linde $5 \mathrm{~A}$

$0.174 \mathrm{~g} \mathrm{CO}_{2} / \mathrm{g} \mathrm{molecular} \mathrm{sieve}$

$12,500 \mathrm{cal} / \mathrm{mole}\left(\max _{3}\right)$

$0.64 \mathrm{~g} / \mathrm{cm}^{3}\left(401 \mathrm{~b} / \mathrm{ft}^{3}\right)$

$0.21 \mathrm{Cal} / \mathrm{g} \cdot{ }^{\circ} \mathrm{C}\left(0.21 \mathrm{Btu} / 1 \mathrm{~b} \cdot{ }^{\circ} \mathrm{F}\right)$

$50 \%$ of heat of adsorption of $\mathrm{CO}_{2}$

$1.01 \times 10^{5} \mathrm{~Pa}(1 \mathrm{~atm})$

$0^{\circ} \mathrm{C}$

$200^{\circ} \mathrm{C}$

Equivalent to molecular sieve heat capacity

Ratio of molecular sieve cross-sectional 0.5 area to total system cross-sectional area

Heat capacity of gases in molecular sieve bed

Bed design gas flow rate

0.0

KALC system concentration of krypton

$50 \mathrm{~cm}^{3} / \mathrm{min}-\mathrm{cm}^{2}$ bed cross section

Ratio of flow rate of molecular sieve system to total system flow rate off-gas volume to molecular sieve system/HTGR fuel block

Gas composition to molecular sieve system

$\mathrm{Cr}_{2}$

1000

1000

$4.5 \times 10^{5} \mathrm{~cm}^{3}\left(1.6 \times 10^{1} \mathrm{scf}\right)$

Other 

Table 5.2. "Design" of $\mathrm{Kr}-\mathrm{CO}_{2}$ sorption system
for full-scale pfant

$\begin{array}{ll}\text { Krypton product concentration } & +50 \% \\ \text { Number of columns } & \text { Three } \\ \text { Diameter of columns } & 51.4 \mathrm{~cm}(20.2 \mathrm{in} .) \\ \text { Height of columns } & 243.8 \mathrm{~cm}(8 \mathrm{ft}) \\ \text { Adsorption cycle time } & 292 \mathrm{~min} \\ \text { Desorption cycle time } & 292 \mathrm{~min} \\ \text { Average cooling capacity required } & 2.877 \mathrm{~kW} \text { at } 0^{\circ} \mathrm{C} \\ \text { for adsorption cycle } & \left(9.82 \times 10^{3} \mathrm{Btu} / \mathrm{hr} \text { at } 0^{\circ} \mathrm{C}\right) \\ \text { Heat required to desorb column } & 25.2 \mathrm{kWhr} \\ & \left(8.60 \times 10^{4} \mathrm{Btu}\right) \\ \text { Cooling required to cool column } & 15.9 \mathrm{kWhr} \\ \text { from zo0 } \mathrm{C} \text { to } 0^{\circ} \mathrm{C} & \left(5.413 \times 10^{4} \mathrm{Btu} \text { at } 0^{\circ} \mathrm{C}\right) \\ \text { Amount of molecular sieve per column } & 1.62 \times 10^{5} \mathrm{~g}(358 \mathrm{lb})\end{array}$

aune column always ready to start adsorption cycle. 
equipment would become excessive because of large column sizes and probably exceed the cost of the actual equipment.

2. The equipment costs are significant. Although no detailed design or cost calculations were made, a system designed by using the assumptions of Table 5.1 would require $1.07 \times 10^{6}$ ib of molecular sieve. At a current price of $\$ 1.47 / 1$ b for large quantities, 38 the cost of the molecular sieve alone would amount to $\$ 1.58$ million.

While replacement of the KALC process by this molecular sieve process is unlikely, the latter process, because it can accept various concentrations of krypton in its feed gas, does allow the KALC designer considerable leeway in his design. Trade-offs in the size and complexity of KALC with this system are possible.

\section{REFERENCES}

1. M. E. Whatley, Calculations on the Performance of the KALC Process, ORNL-4859 (ApriT 1973).

2. T. M. Gilliam, A. D. Ryon, V. L. Fowler, and D. J. Inman, Krypton Adsorption in Liquid $\mathrm{CO}_{2}$ (KALC): Campaign III System Experimental Engineering Section Off-Gas Decontamination Facility, ORNL/TM-5655 (in press).

3. National Council on Radiation Protection and Measurements, Krypton-85 in the Atmosphere - Accumulation, Biological Significance, and Control Technology, NCRP Report No. 44 (July 1, 1975).

4. Allied Chemical Corporation, Idaho National Engineering Laboratory, HTGR Fuel Reprocessing Facility System Design Descriptions for offGas Cleanup SysteII, SDD 1.3A (June 1975). 
5. R. A. Brown, M. Hoza, and D. A. Knecht, "85 Kr Storage by Zeolite Encapsulation," Proceedings of the 14th ERDA Air Cleaning Conference, Sun Valley, Idaho, Aug. 2-4, 1976, CONF-760822.

6. M. Anbar and P. Perlstein, "Mechanism of Radiolysis of Carbon Dioxide," Trans. Faraday Soc. 62, 1803 (1966).

7. C. W. Forsberg, internal program report, Selection of a Process to Remove Carbon Dioxide from a Krypton Gas Mixture, GCR-76/4 (January 1977).

8. A. R. Anderson and J. V. F. Best, "Effects of Oxygen on the Radiulysts of Gaseous Carbon Dioxide," pp. 231-46 in Radiation Chemistry, Vol. II: Gases, Solids, Organic Liquids, Adv. Chem. Ser. 82, American Chemical Society, 1968.

9. R. W. Glass, P. A. Haas, R. S. Lowrie, and M. E. Whatley, HTGR HeadEnd Processing - A Preliminary Evaluation of Processes for Decontaminating Burner Off-Gas, ORNL/TM-3527 (July 1972).

10. S, Strelzoff, "Choosing the Optimum $\mathrm{CO}_{2}$-Removạl System," Chem. Eng. $\underline{8} \underline{\theta}(9), 115$ (1975).

11. A. G. Croff, An Evaluation of Options Relative to the Fixation and Disposal of ${ }^{14} \mathrm{C}$-Contaminated $\mathrm{CO}_{2}$ as $\mathrm{CaCO}_{3}$, ORNL/TM-5171 (April 1976).

12. D. W. Holladay, The Use of a Gas-Slaked Lime Slurry Contactor for the Fixation of Carbon-14-Contaminated $\mathrm{CO}_{2}$ from the KALC Off-Gas, URNL/TM-5757 (in preparation).

13. S. Ross and J. P. Olivier, On Physical Adsorption, Interscience, New York, 1964.

14. D. W. Breck, Zeolite Molecular Sieves, Wiley, New York, 1974. 
15. K. J. Notz, Selected Studies in HTGR Reprocessing Development, ORNL/TM-5328 (March 1976).

16. Union Carbide Corporation, "Carbon Dioxide Adsorption, Isotherm Data Sheet No. 21."

17. C. J. Major, B. J. Sollami, and K. Kammermeyer, "Carbon Dioxide Removal from Air by Adsorbents," Ind. Eng. Chem., Process Design Develop. 4(3), 327 (July 1965).

18. Union Carbide Corporation, "Carbon Dioxide Adsorption, Isotherm Data Sheet No. 22."

19. S. Kitani and J. Takada, "Adsorption of Krypton and Xenon on Various Adsorbents," J. Nucl. Sci. Technol. 2(2), 51 (Feb. 1965).

20. E. Wirsing, Jr., L. P. Hatch, and B. F. Dodge, Low Temperature Adsorption of Krypton on Solid Adsorbents, BNL-50254 (T-586) (June 1970).

21. M. H. Lloyd and R. A. McNees, Adsorption of Krypton and Xenon by Various Materials, ORNL-3228 (Nov. 16, 1961).

22. C. L. Carnahan, Gas-Chromatographic Separations of Rare Gases, USNRDL-TR-535 (Nov. 2, 1961).

23. R. D. Ackley and W. E. Browning, Jr., internal memorandum, "Equilibrium Adsorption of Krypton and Xenon on Activated Carbon and Linde Molecular Sieves," ORNL-CF-61-2-32 (Feb. 14, 1961).

24. Y. Yuasa, M. Ohta, A. Watanabe, A. Tani, and N. Takashima, "Selective Adsorption-Desorption Method for the Enrichment of Krypton," presented at the 13th USAEC Air Cleaning Conference, San Francisco, Calif., Aug. 12-15, 1974. 
25. L. C. Lewis, Evaluation of Adsorbents for Purification of Noble Gases in Dissolver Off-Gas, IN-1402 (July 1970).

26. K. Kawazoe and T. Kawai, "Investigation of Effective Diffusivities and Equilibria of Trace Component in Adsorption at Elevated Pressures," Kagaku Kogaku $\underline{36}(1), 71$ (1972).

27. Union Carbide Corporation, "Carbon Dioxide Adsorption, Isotherm Data Sheet No. 24,"

28. Union Carbide Corporation, "Oxygen Adsorption, Isotherm Data Sheet Nó. $51 . "$

29. S. Claesson, "Studies on Adsorption and Adsorption Analysis with Special Reference to Homologous Series," Ark. Kemi, Mineral., Geol., Band 23A, No. 1 (1946).

30. R. Kaiser, Gas Phase Chromatography, Butterworths, London, 1963.

31. C. K. Hersh, Molecular Sieves, pp. 53-90, Reinhold, New York, 1961.

32. W. M. Meier and J. B. Uytterhoeven, Molecular Sieves, Adv. Chem. Ser. 121, American Chemical Society, 1973.

33. Proceedings of the Second International Conference on Molecular Sieve Zeolites, Worcester, Mass., Sept. 8-11, 1970.

34. D. M. Levins, R. W. Glass, M. M. Chiles, and D. J. Inman, Monitoring and Analysis of Process Streams in a Krypton-85 Off-Gas Decontamination System, ORNL/TM-4923 (July 1975).

35. K. J. Notz, An Overview of HTGR Fuel Recycle, ORNL/TM-4747 (Jâriuary 1976).

36. K. J. Notz, Selected Studies in HTGR Reprocessing Development, ORNL/TM-5328 (March 1976). 
37. Union Carbide Corporation, Linde Molecular Sieve Fixed-Bed

Pressure Drop Calculations, Linde Molecular Sieves Adsorbent Bulletin F34A.

38. Cattello, Linde Division, Union Carbide Corporation, private communication, June 30, 1976.

39. C. W. Forsberg, "Separation of Krypton from Carbon Dioxide and Oxygen with Molecular Sieves," Proceedings of the 14th ERDA Air Cleaning Conference, Aug. 2-4.1976, Sun Valley, Idaho, CONF760822-3. 


\section{THIS PAGE}

\section{WAS INTENTIONALLY \\ LEFT BLANK}


APPENDIX A: COMPUTER PROGRAM TO DETERMINE MAXIMUM KRYPTON PRODUCT CONCENTRATION 39 


\section{THIS PAGE}

\section{WAS INTENTIONALLY \\ LEFT BLANK}


COMP ILER OPTIONS - NAME $=$ MAIN, OPT $=00$, LINECNT $=60,5 I Z E=0000 \mathrm{~K}$

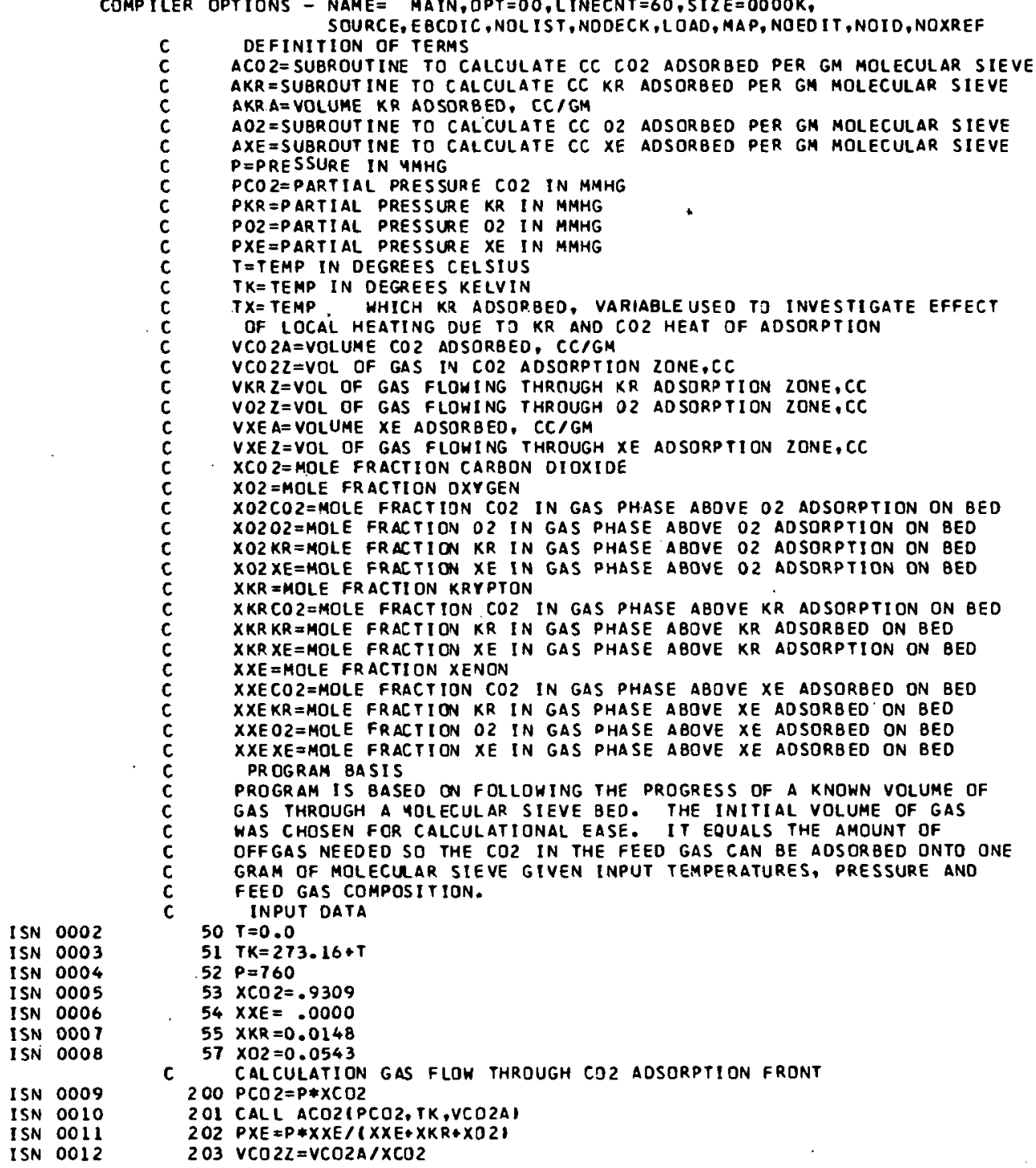




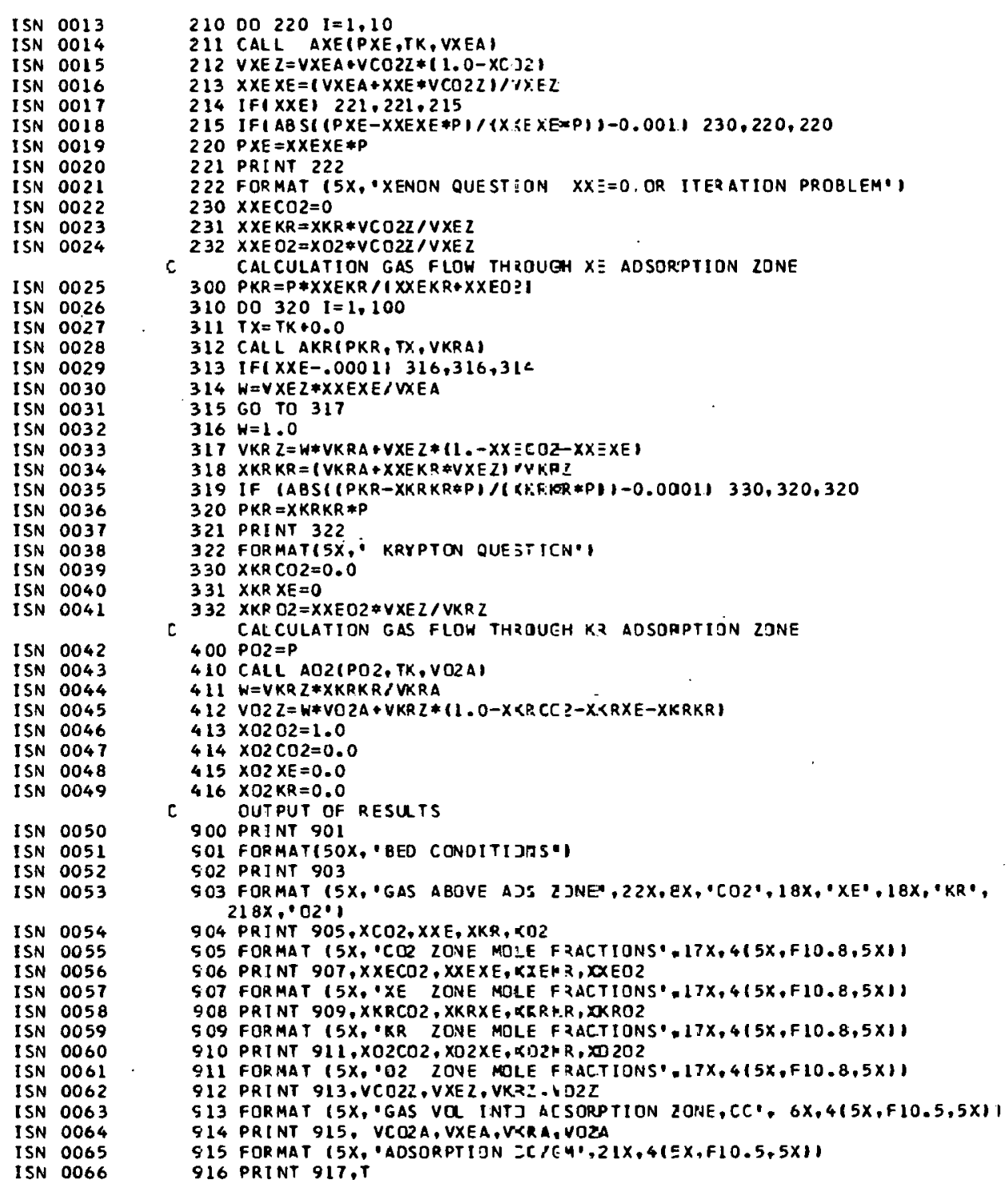




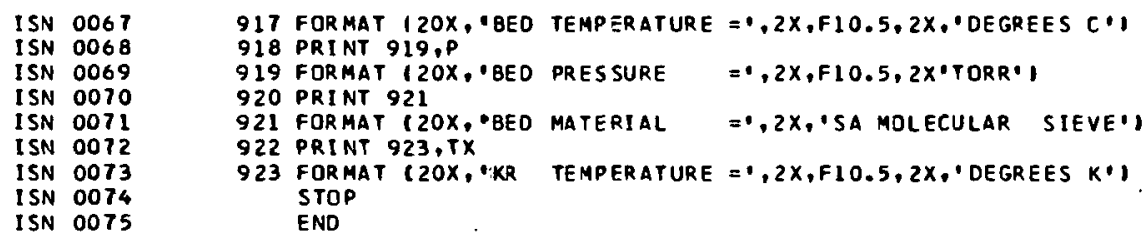

COMPILER OPTIONS - NAME $=$ MAIN, OPT $=00, L$ INECNT $=60,5 I Z E=0000 \mathrm{~K}$,

ISN 0002 SOURCE, EBCDIC, NOL IST, NODECK, LOAD, MAP, NOEOIT, NOID, NOXREF. SUBROUTINE AXE(PXE,TK,VXEAI $C$
B BASEO ON GRAPH S. KITANI AND J. TAKADA AOSJRPTION OF KRYPTON TEC HNOLOGY 2, NO 2,PG. 51-56 FEB, 1965 .

ISN 0004
ISN 0005 O.8 FACTOR IN EOUATION BECAUSE MS IS O. END

COMP ILER OPTIONS - NAME $=$ MAIN,OPT $=00, L$ INECNT $=60,5 I Z E=0000 \mathrm{~K}$,

$\begin{array}{ll}\text { ISN } & 0002 \\ \text { ISN } & 0003\end{array}$ SUB ROUTINE AKR, EBCDIC, NOL IST, NODECK, LOAD, MAP, NOEDIT, NOIO, NOXRE VKR $=0.80 \% 0.0007 \approx P K R * E X P(3500.1(1.9872 * T X) 1 / S Q R T(T X)$ EQUATION IN SO STITANI ANO J. TARAOA ADSORPTION OF KRYPTON
AND XENON ON VARIOUS ADSORBANTS J. NUCLEAR SCIENCE AND

$\begin{array}{ll}\text { ISN } 0004 & \text { RETURN } \\ \text { ISN } 0005 & \text { END }\end{array}$ TECHNOLOGY 2, DO 2,PG. 51-56 FEB, 1965

COMPILER OPTIONS - NAME $=$ MAIN, OPT $=00, L I N E C N T=60,5 I Z E=0000 \mathrm{~K}$,

ISN 0002 SUBROUTINE ACO, EBCDIC, NOLIST, NODECK, LOAD, MAP, NOED IT , NOID, NOXRE SUBROUTINE ACO2 $P$ CO2, TK, VCO2A

ISN 0004

VCO2A $=51.4360+6.8 E 1$ B5*ALOGI PCO2I
C ASSUMES OO OEGREES C B BEO, 200 OEGREES C BAKEOUT AT BELOM 10 TORR DATA FROM LINGE ISOTHERM DATA SHEET 22

ISN 0005 RETURN
END

COMP ILER OPTIONS - NAME = MAIN, OPT $=00, \angle I N E C N T=60,512 E=0000 \mathrm{~K}$

$\begin{array}{ll}\text { ISN } & 0002 \\ \text { ISN } & 0003 \\ \text { ISN } & 0004 \\ \text { ISN } 0005\end{array}$

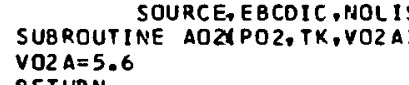


XENON OUESTION XXE=0 OR ITERATION PE:QBLEM

GAS ABOVE ACS $20 N E$ BED CONDITIONS

GAS ABOVE ACS 2 ONE
COZ ZONE MOLE FRACTIONS

XE ZONE MOLE FRACTIONS

0.93089998

0.0

0.0

ZONE NOLE FRACTIONS

GAS VOL INTC ADSOF.PTION ZONE, CC

GASORPTION CC/GM

103.61530
96.45549

DECREES

BED PRESSURE $=730.00000$ TOF.R

BED MATERIAL $=$ SA MOLECULAR SIEVE
KR TEMPERATURE $=273.15991$ OECREES K

0.01480000

0. 31418214

0.59524223

13. $\$ 6158$

02

0.05430500

0.78581738
0.30475171

0.30475771

$11.98 \in 15$

5.60000

IHCOO2I STOF

o 
ORNL/TM-5826

Dist. Category UC-77

\section{INTERNAL DISTRIBUTION}

1. P. Angelini

2. B. J. Baxter.

3. R. L. Beatty

4. R. E. Blanco

5. J. 0. Blomeke

6. R. A. Bradley

7. R. E. Brooksbank

8. W. L. Carter

9. J. H. Coobs

10. A. G. Croff

11. W. Davis

12. R. G. Donnelly

13. W. P. Eatherly

14. D. E. Ferguson

15-24. C. W. Forsberg

25. V. L. Fowler

26. T. M. Gilliam

27. R. W. Giass

28. W. S. Groenier

29. G. L. Haag

30. P. A. Haas

31. W. R. Hame1

32. F. E. Harrington

33. C. C. Haws

34. D. W. Holladay

35. F. J. Homan

36. D. J. Inman

37. D. R. Johnson

38-45. P. R. Kasten

46. J. J. Kurtz

47. W. J. Lackey

48. R. E. Leuze

49. K. H. Lin

50-51. A. L. Lotts

52. J. E. Mack
53. A. P. Malinauskas

54. M. M. Martin

55. S. R. McNeany

56-57. K. J. Notz

58. A. R. 01 sen

59. D. P. Reid

60. H. D. Ringel

61. J. W. Roddy

62. J. E. Rushton

63. A. D. Ryon

64. T. F. Scanlan

65. C. D. Scott

66. J. W. Snider

67. M. J. Stephenson

68. D. P. Stinton

69. R. R. Suchome1

70. S. M. Tiegs

71. T. N. Tiegs

72. D. B. Trauger

73. W. E. Unger

74. J. E. Van Cleve

75. V. C. A. Vaughen

76. B. L. Vondra

77. J. R. Weir

78-79. R. G. Wymer

80-81. Central Research Library

82. Document Reference Section

83. ORNL Patent Section

84-85. Laboratory Records

86. Laboratory Records, R.C.

87. G. R. Choppin (consultant)

88. E. L. Gaden, Jr. (consultant)

89. C. H. Ice (consultant)

:90. L. E. Swabb, Jr. (consultant)

91. K. D. Timmerhaus (consultant)

EXTERNAI, DISTRIBIITION

92. Research and Technical Support Division, ERDA, ORO, P. O. Box E, Oak Ridge, Tennessee 37830

93. Director, Reactor Division, ERDA, ORO, P. O. BOx E, Oak Ridge, Tennessee 37830 
EXTERNAL DISTRIBUTION (cont'd)

94-95. Director, Division of Waste Management, Production, and Reprocessing, ERDA, Washington, D.C. 20545

96. Assistant Director for Fuel Cycle, Division of Waste Management, Production, and Reprocessing, ERDA, Washington, D.C. 20545

97. Chief, Technology Branch, Division of Waste Management, Production, and Reprocessing, ERDA, Washington, D.C. 20545

98. Chief, Industrial Programs Branch, Division of Waste Management, Production, and Reprocessing, ERDA, Washington, D.C. 20545

99-100. Director, Division of Reactor Development and Demonstration, ERDA, Washington, D.C. 20545

101-281. Given distribution as shown in TID-4500 under Gas-Cooled Reactor Technology category ( 26 copies - NTIS) 